\title{
Changing wildfire, changing forests: the effects of climate change on fire regimes and vegetation in the Pacific Northwest, USA
}

\author{
Jessica E. Halofsky ${ }^{1 *}$ (D), David L. Peterson ${ }^{2}$ and Brian J. Harvey ${ }^{2}$
}

\begin{abstract}
Background: Wildfires in the Pacific Northwest (Washington, Oregon, Idaho, and western Montana, USA) have been immense in recent years, capturing the attention of resource managers, fire scientists, and the general public. This paper synthesizes understanding of the potential effects of changing climate and fire regimes on Pacific Northwest forests, including effects on disturbance and stress interactions, forest structure and composition, and post-fire ecological processes. We frame this information in a risk assessment context, and conclude with management implications and future research needs.

Results: Large and severe fires in the Pacific Northwest are associated with warm and dry conditions, and such conditions will likely occur with increasing frequency in a warming climate. According to projections based on historical records, current trends, and simulation modeling, protracted warmer and drier conditions will drive lower fuel moisture and longer fire seasons in the future, likely increasing the frequency and extent of fires compared to the twentieth century. Interactions between fire and other disturbances, such as drought and insect outbreaks, are likely to be the primary drivers of ecosystem change in a warming climate. Reburns are also likely to occur more frequently with warming and drought, with potential effects on tree regeneration and species composition. Hotter, drier sites may be particularly at risk for regeneration failures.

Conclusion: Resource managers will likely be unable to affect the total area burned by fire, as this trend is driven strongly by climate. However, fuel treatments, when implemented in a spatially strategic manner, can help to decrease fire intensity and severity and improve forest resilience to fire, insects, and drought. Where fuel treatments are less effective (wetter, high-elevation, and coastal forests), managers may consider implementing fuel breaks around high-value resources. When and where post-fire planting is an option, planting different genetic stock than has been used in the past may increase seedling survival. Planting seedlings on cooler, wetter microsites may also help to increase survival. In the driest topographic locations, managers may need to consider where they will try to forestall change and where they will allow conversions to vegetation other than what is currently dominant.
\end{abstract}

Keywords: adaptation, climate change, disturbance regimes, drought, fire regime, Pacific Northwest, regeneration, vegetation

\footnotetext{
*Correspondence: Jessica.halofsky@usda.gov

'US Department of Agriculture, Forest Service, Pacific Northwest Research Station, Olympia Forestry Sciences Lab, 3625 93rd Avenue SW, Olympia, Washington 98512, USA

Full list of author information is available at the end of the article
}

\section{Springer Open}

(c) The Author(s). 2020 Open Access This article is licensed under a Creative Commons Attribution 4.0 International License, which permits use, sharing, adaptation, distribution and reproduction in any medium or format, as long as you give appropriate credit to the original author(s) and the source, provide a link to the Creative Commons licence, and indicate if changes were made. The images or other third party material in this article are included in the article's Creative Commons licence, unless indicated otherwise in a credit line to the material. If material is not included in the article's Creative Commons licence and your intended use is not permitted by statutory regulation or exceeds the permitted use, you will need to obtain permission directly from the copyright holder. To view a copy of this licence, visit http://creativecommons.org/licenses/by/4.0/. 


\section{Resumen}

Antecedentes: Los incendios de vegetación en el Noroeste del pacífico (Washington, Oregon, Idaho, y el oeste de Montana, EEUU), han sido inmensos en años recientes, capturando la atención de los gestores de recursos, de científicos dedicados a los incendios, y del público en general. Este trabajo sintetiza el conocimiento de los efectos potenciales del cambio climático y de los regímenes de fuego en bosques del noroeste del Pacífico, incluyendo los efectos sobre las interacciones entre disturbios y distintos estreses, la estructura y composición de los bosques, y los procesos ecológicos posteriores. Encuadramos esta información en el contexto de la determinación del riesgo, y concluimos con implicancias en el manejo y la necesidad de futuras investigaciones.

Resultados: Los incendios grandes y severos en el Noroeste del Pacífico están asociados con condiciones calurosas y secas, y tales condiciones muy probablemente ocurran con el incremento en la frecuencia del calentamiento global. De acuerdo a proyecciones basadas en registros históricos, tendencias actuales y modelos de simulación, condiciones prolongadas de aumento de temperaturas y sequías conducirán a menores niveles de humedad, incrementando probablemente la frecuencia y extensión de fuegos en el futuro, en comparación con lo ocurrido durante el siglo XX. Las interacciones entre el fuego y otros disturbios, son probablemente los principales conductores de cambios en los ecosistemas en el marco del calentamiento global. Los incendios recurrentes podrían ocurrir más frecuentemente con aumentos de temperatura y sequías, con efectos potenciales en la regeneración de especies forestales y en la composición de especies. Los sitios más cálidos y secos, pueden estar particularmente en riesgo por fallas en la regeneración.

Conclusiones: Los gestores de recursos no podrían tener ningún efecto sobre el área quemada, ya que esta tendencia está fuertemente influenciada por el clima. Sin embargo, el tratamiento de combustibles, cuando está implementado de una manera espacialmente estratégica, puede ayudar a reducir la intensidad y severidad de los incendios, y mejorar la resiliencia de los bosques al fuego, insectos, y sequías. En lugares en los que el tratamiento de combustibles es menos efectivo (áreas más húmedas, elevadas, y bosques costeros) los gestores deberían considerar implementar barreras de combustible alrededor de valores a proteger. Cuando y donde la plantación post fuego sea una opción, plántulas provenientes de diferentes stocks genéticos de aquellos que han sido usados en el pasado pueden incrementar su supervivencia. La plantación de plántulas en micrositios más húmedos y fríos podría ayudar también a incrementar la supervivencia de plántulas. En ubicaciones topográficas más secas, los gestores deberían considerar evitar cambios y donde estos sean posibles, permitir conversiones a tipos de vegetación diferentes a las actualmente dominantes.

\section{Abbreviations}

ENSO: El Niño-Southern Oscillation

MPB: Mountain Pine Beetle

PDO: Pacific Decadal Oscillation

\section{Introduction}

Large fires are becoming a near-annual occurrence in many regions globally as fire regimes are changing with warming temperatures and shifting precipitation patterns. The US Pacific Northwest (states of Washington, Oregon, Idaho, and western Montana, USA; hereafter the Northwest) is no exception. In 2014, the largest wildfire in recorded history for Washington State occurred, the 103640 ha Carlton Complex Fire (Fig. 1). In 2015 , an extreme drought year with very low snowpack across the Northwest (Marlier et al. 2017), 688000 ha burned in Oregon and Washington (Fig. 2), with over 3.6 million ha burned in the western United States. Several fires in 2015 occurred in conifer forests on the west (i.e., wet) side of the Cascade Range, including a rare fire event in coastal temperate rainforest on the Olympic Peninsula. In some locations, short-interval reburns have occurred. For example, one location on Mount Adams in southwestern Washington burned three times between 2008 and 2015 (Fig. 3). Similarly, during the summer of 2017 in southwestern Oregon, the 77000 ha Chetco Bar Fire burned over 40000 ha of the 2002 Biscuit Fire, including a portion of the Biscuit Fire that had burned over part of the 1987 Silver Fire. At over 200000 ha, the Biscuit Fire was the largest fire in the recorded history of Oregon.

Over the twentieth century in the Northwest, years with relatively warm and dry conditions have generally corresponded with larger fires and greater area burned (Trouet et al. 2006; Westerling et al. 2006; Littell et al. 2009; Littell et al. 2010; Abatzoglou and Kolden 2013; Cansler and McKenzie 2014; Dennison et al. 2014; Stavros et al. 2014; Westerling 2016; Kitzberger et al. 2017; Reilly et al. 2017; Holden et al. 2018). Decreasing fuel moisture and increasing duration of warm, dry weather creates large areas of dry fuels that are more likely to ignite and carry fire over a longer period of time (Littell et al. 2009).

A warming climate will have profound effects on fire frequency, extent, and possibly severity in the Northwest. 


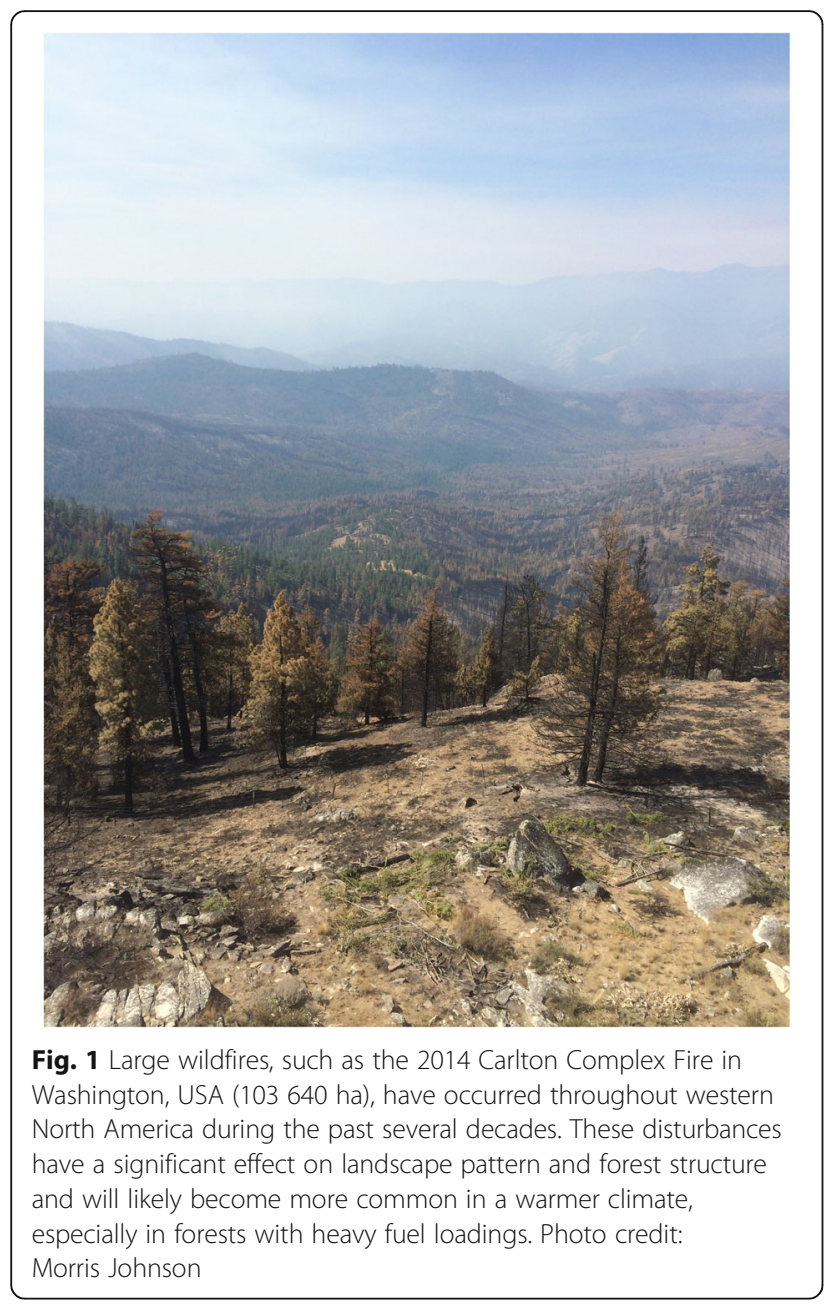

Increased temperatures are projected to lengthen fire and growing seasons, increase evaporative demand, decrease soil and fuel moisture, increase likelihood of large fires, and increase area burned by wildfire (McKenzie et al. 2004; Littell et al. 2010; Stavros et al. 2014; Westerling 2016). Decreased summer precipitation is also projected to increase area burned (Holden et al. 2018).

Interactions between fire and other disturbance agents (e.g., drought, insect outbreaks) will likely catalyze ecosystem changes in a warming climate. Increased tree stress and interacting effects of drought may also contribute to increasing wildfire severity (damage to vegetation and soils) and area burned (McKenzie et al. 2009; Stavros et al. 2014; Littell et al. 2016; Reilly et al. 2017).

Climatic changes and associated stressors can interact with altered vegetation conditions (e.g., those resulting from historical management practices) to affect fire frequency, extent, and severity, as well as forest conditions in the future (Keeley and Syphard 2016). Human influence through domestic livestock grazing, road construction, conversion of land to agriculture, and urbanization has resulted in (direct or indirect) exclusion of fires in dry forests (Hessburg et al. 2005). Many larger, fireresistant trees have been removed by selective logging. These activities, along with active fire suppression, have resulted in increased forest density and fuel buildup in forests historically characterized by frequent, lowseverity and mixed-severity fires (Hessburg et al. 2005). Although landscape pattern and fuel limitations were key factors that limited fire size and severity historically, these limitations have been largely removed from many contemporary landscapes, thus increasing the potential for large high-severity fires, particularly in a warming climate.

Facing such changes, land managers need information on the magnitude and likelihood of altered fire regimes and forest conditions in a warming climate to help guide long-term sustainable resource management. Many published studies have explored the potential effects of climate change on forest fire in the Northwest, including paleoecological, modeling, and local- to regional-scale empirical studies. However, to our knowledge, there is no single resource that synthesizes these varied studies for the Northwest region. A synthesis of this information can help managers better understand the potential effects of climate change on ecosystem processes, assess risks, and implement actions to reduce the negative effects of climate change and transition systems to new conditions.

In this synthesis, we draw from relevant published literature to discuss potential effects of changing climate on fire frequency, extent, and severity in Northwest forests. Sources of information include: (1) long-term (centuries to millennia) paleoecological studies of climate, fire, and species distribution; (2) medium-term (decades to centuries) fire history studies; (3) near-term (years to decades) studies on trends in vegetation and fire associated with recent climatic variability and change; (4) forward-looking studies using simulation models to project future fire and vegetation change; and (5) recent syntheses focused on potential climate change effects.

We used regionally specific information where possible, including information from adjacent regions with forests of similar structure and function when relevant. Following an overview of climate projections, we (1) identified risks related to wildfire as affected by climate change in three broad ecosystem types; (2) explored the magnitude and likelihood of those risks; and (3) concluded with a discussion of uncertainties about future climate and fire, potential future research, and implications for resource management.

\section{Overview of climate projections}

Warming temperatures and changing precipitation patterns will affect amount, timing, and type of precipitation; snowmelt timing and rate (Luce et al. 2012; Luce et al. 


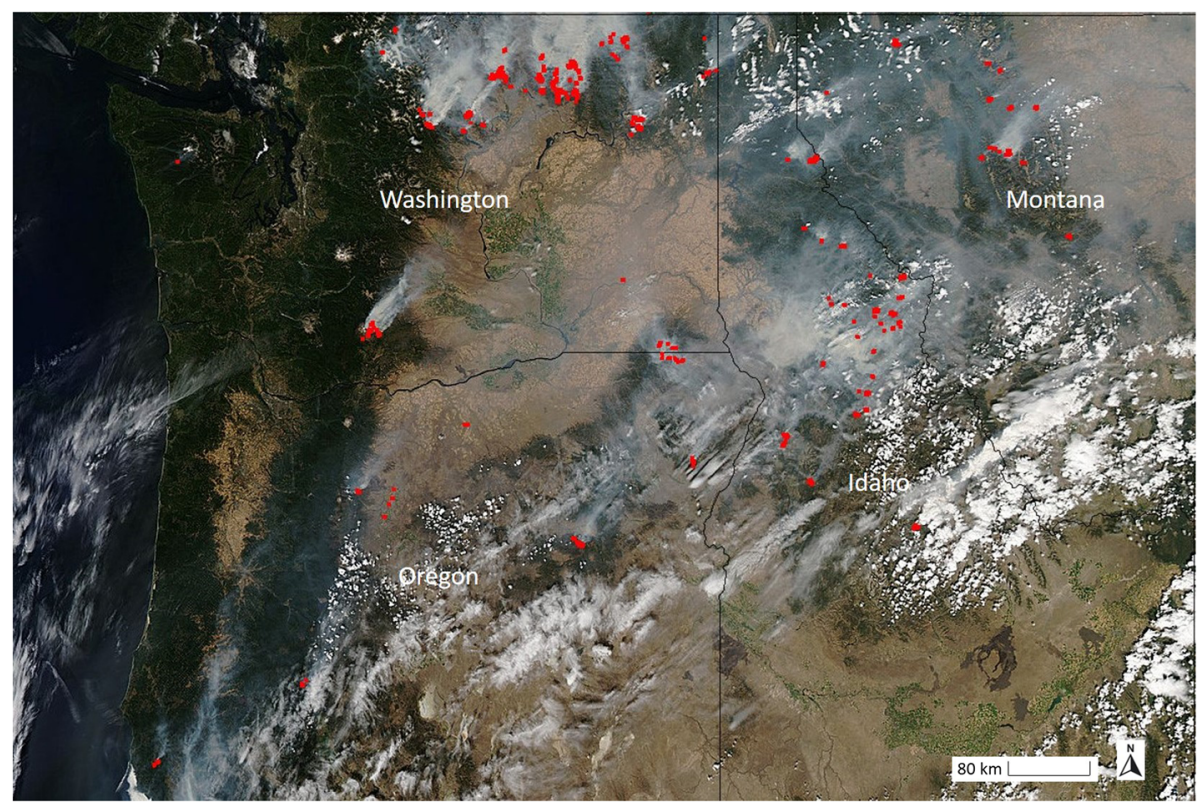

Fig. 2 Fires burning across the Pacific Northwest, USA, on 25 August 2015. This natural-color satellite image was collected by the Moderate Resolution Imaging Spectroradiometer (MODIS) aboard the Aqua satellite. Actively burning areas, detected by MODIS's thermal bands, are outlined in red. National Aeronautics and Space Administration image courtesy of Jeff Schmaltz, MODIS Rapid Response Team

2013; Safeeq et al. 2013); streamflow magnitude (Hidalgo et al. 2009; Mantua et al. 2010); and soil moisture content (McKenzie and Littell 2017). Compared to the historical period from 1976 to 2005, 32 global climate models project increases in mean annual temperature for the middle and end of the twenty-first century in the Northwest. These projected increases range from 2.0 to $2.6{ }^{\circ} \mathrm{C}$ for mid-century (2036 to 2065) and 2.8 to $4.7^{\circ} \mathrm{C}$ for the end of the century (2071 to 2100), depending on future greenhouse gas emissions (specifically representative concentration pathway 4.5 or 8.5; Vose et al. 2017). Warming is expected to occur during all seasons, although most models project the largest temperature increases in summer (Mote et al. 2014). All models suggest a future increase in heat extremes (Vose et al. 2017).

Changes in precipitation are less certain than those for temperature. Global climate model projections for annual average precipitation range from -4.7 to $+13.5 \%$, averaging about $+3 \%$ among models (Mote et al. 2014). A majority of models project decreases in summer precipitation, but projections for precipitation vary for other seasons. However, models agree that extreme precipitation events (i.e., number of days with precipitation $>2.5 \mathrm{~cm}$ ) will likely increase, and that the length of time between precipitation events will increase (Mote et al. 2014; Easterling et al. 2017).

\section{Risk assessment}

A risk-based approach to climate change vulnerability assessments provides a common framework to evaluate potential climate change effects and identify a structured way to choose among adaptation actions or actions to mitigate climate change risks (EPA 2014). Risk assessment is linked with risk management by (1) identifying risks-that is, how climate change may prevent an agency or other entity from reaching its goals; (2) analyzing the potential magnitude of consequences and likelihood for each risk; (3) selecting a set of risk-reducing actions to implement; and (4) prioritizing those actions that address risks with the highest likelihood and magnitude of consequences (EPA 2014).

Here, we summarized potential risks that are relevant for natural resource management associated with climate-fire interactions, including: wildfire frequency, extent, and severity; reburns; stress interactions; and regeneration for (1) moist coniferous forest (low to mid elevation), (2) dry coniferous forest and woodland (low to mid elevation), and (3) subalpine coniferous forest and woodland (high elevation). The likelihood and magnitude of consequences, and confidence in inferences are described for each risk. Although the information provided here does not constitute risk management, as described in the previous paragraph, this information can be used to inform more site- and resource-specific risk assessments and risk management.

The risks identified here were inferred from the authors' review of the published literature described below, as well as experience with developing climate change vulnerability assessments in the study region over the past decade (Halofsky et al. 2011a, b; Raymond et al. 
a

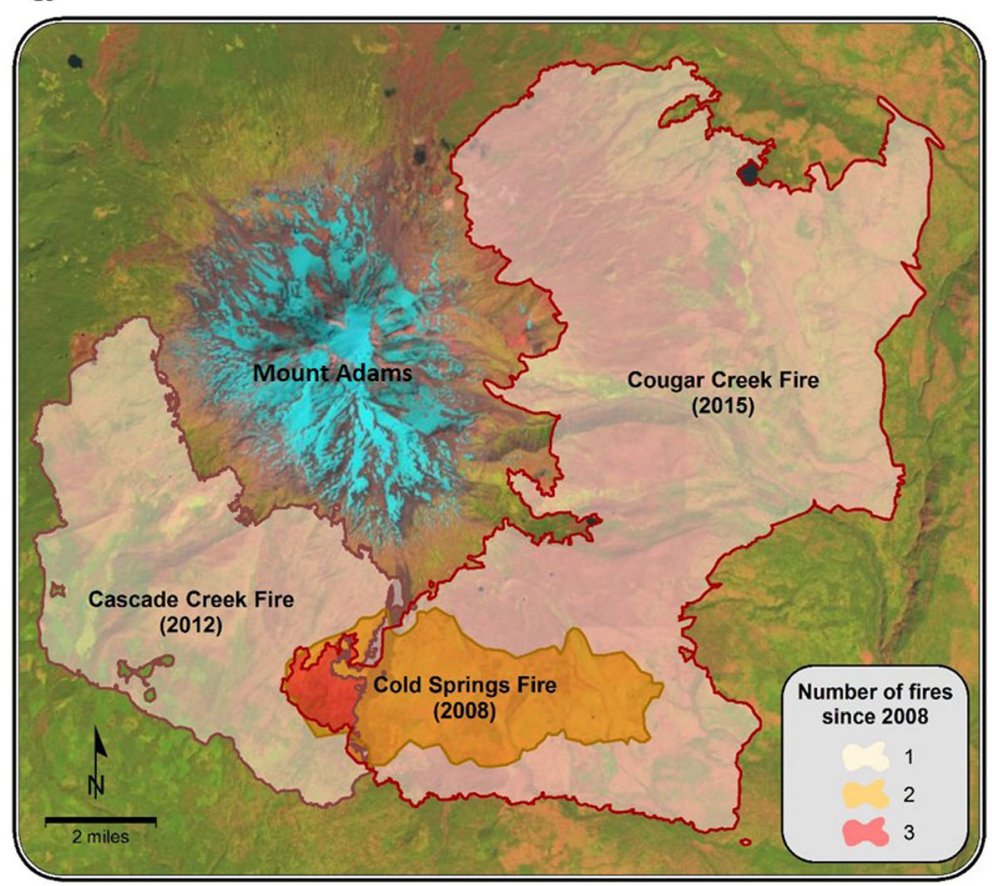

b

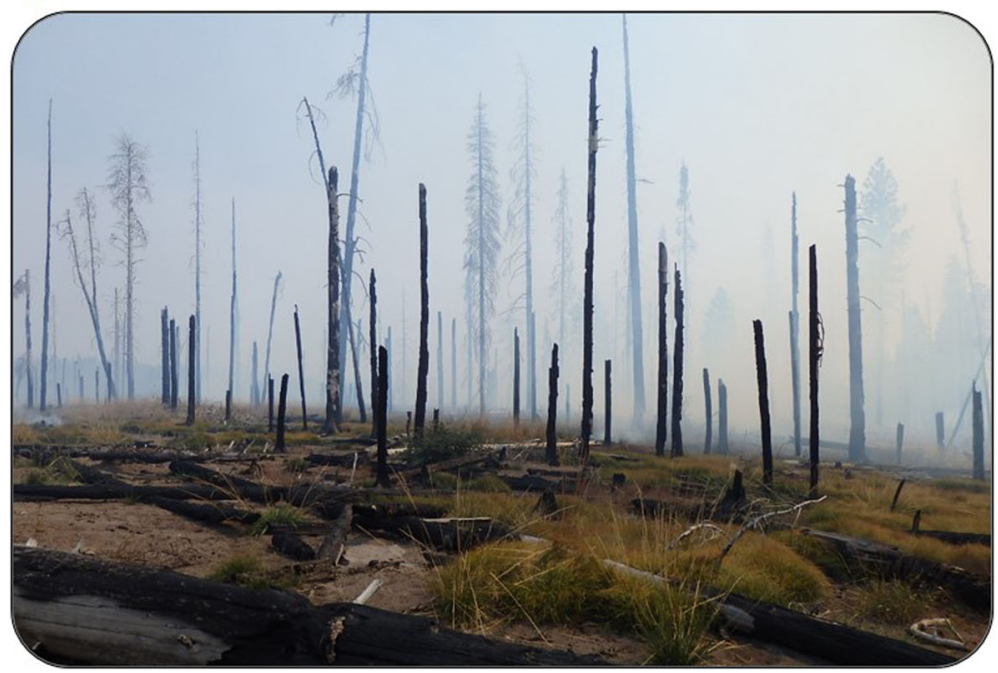

Fig. 3 (a) Large fires around Mount Adams in Gifford Pinchot National Forest in southwestern Washington, USA, between 2001 and 2015 (area in orange burned twice, and area in red burned three times); and (b) area in Gifford Pinchot National Forest that has burned three times since 2008 (2008 Cold Springs fire, 2012 Cascade Creek fire, and 2015 Cougar Creek fire). Map credit: Robert Norheim; photo credit: Darryl Lloyd

2014; Halofsky and Peterson 2017a, b; Halofsky et al. 2019; Hudec et al. 2019). These assessments encompassed all ecosystems and species addressed in this synthesis, and included extensive discussion of the effects of wildfire and other disturbances. Climate change effects and adaptation options in the assessments were greatly informed by input from resource managers as well as by scientific information. Thus, many fire- related vulnerabilities identified in the assessments are relevant to the risk assessment discussed here.

\section{Risk in moist coniferous forests}

Most climate-fire risks in moist coniferous forests are relatively low (Table 1). These forests occur west of the Cascade Range in Oregon and Washington and are frequently dominated by Douglas-fir (Pseudotstuga menziesii [Mirb.] 
Table 1 Risk assessment for the effects of fire-climate interactions in moist coniferous forest, low to mid elevation (Olympics, westside Cascades, northern Idaho, west-side Rocky Mountains, USA), for the mid to late twenty-first century. Likelihood and confidence are rated low, moderate, and high. Low likelihood represents consequences that are unlikely (approximately 0 to 33\% probability), moderate likelihood represents consequences that are about as likely as not (approximately 33 to $66 \%$ probability), high likelihood represents consequences that are likely to very likely (approximately 66 to 100\% probability). Low confidence is characterized by low scientific agreement and limited evidence, whereas high confidence is characterized by high scientific agreement and robust evidence, with moderate confidence falling between those two extremes

\begin{tabular}{llll}
\hline Fire-climate interaction & Magnitude of consequences & Likelihood of consequences & Confidence \\
\hline Wildfire frequency & Small increase & Low & High \\
Wildfire extent & Small increase & Low & Moderate \\
Wildfire severity & No change to small increase & Low & Moderate \\
Reburns & No change to small increase & Low & Moderate \\
Stress interactions & Small increase & Low to moderate & Moderate \\
Regeneration & No change to small decrease & Low & Low \\
\hline
\end{tabular}

Franco) and western hemlock (Tsuga heterophylla [Raf.] Sarg.). Moist coniferous forests are characterized by an infrequent, stand-replacing (i.e., high-severity) fire regime (Agee 1993). Although fire frequency and severity may increase with climate change, the frequency of fire in these moist ecosystems will likely remain relatively low.

\section{Risk in dry coniferous forests}

Climate-fire risks in dry coniferous forests and woodlands are high for increased fire frequency, extent, and severity (Table 2). Dry coniferous forests and woodlands occur at lower elevations in southwestern Oregon, east of the Cascade Range in Oregon and Washington, and at lower elevations in the Rocky Mountains in Idaho and Montana. Fire regimes in these forests and woodlands range from moderate frequency and mixed severity to frequent and low severity. Ponderosa pine (Pinus ponderosa Douglas ex P. Lawson \& C. Lawson) is a characteristic species, along with Douglas-fir, grand fir (Abies grandis [Douglas ex D. Don] Lindl.), and white fir (Abies concolor [Gordon \& Glend.] Lindl. ex Hildebr.). These forests and woodlands are also at risk from interacting disturbances and hydrologic change (moderate to high likelihood and magnitude of consequences), and postfire regeneration failures are likely to occur on some sites.

\section{Risk in high-elevation forests}

Climate-fire risks in high-elevation forests are moderate, with a primary factor being increased fire frequency and extent in lower-elevation forests spreading to higherelevation systems (Table 3). Regeneration could be challenging in locations where seed availability is low due to very large fires. High-elevation forests occur in mountainous areas across the Northwest. They are characterized by species such as subalpine fir (Abies lasiocarpa [Hook.] Nutt.), mountain hemlock (Tsuga mertensiana [Bong.] Carrière), and lodgepole pine (Pinus contorta var. contorta Engelm. ex S. Watson). High-elevation forests are characterized by infrequent, stand-replacement fire regimes (Agee 1993). Risks of stress interactions are also moderate, because drought and insect outbreaks will likely affect high-elevation forests with increasing frequency.

\section{Historical and contemporary fire-climate relationships}

\section{Paleoclimate and fire data}

Wildfire-derived charcoal deposited in lake sediments can be used to identify individual fire events and to estimate fire frequency over hundreds to thousands of years (Itter et al. 2017). In combination with sediment pollen records, charcoal records help to determine how vegetation and fire frequency and severity shifted with climatic variability in the past (Gavin et al. 2007). Existing paleoecological reconstructions of the Northwest are based mostly on pollen and charcoal records from lakes in forested areas west of the Cascade Range, with few studies in the dry interior of the region (Kerns et al. 2017).

The early Holocene (circa 10500 to 5000 years BP) was the warmest post-glacial period in the Northwest (Whitlock 1992). During the early Holocene, summers were warmer and drier relative to recent historical conditions, with more intense droughts (Whitlock 1992; Briles et al. 2005). In many parts of the Northwest, these warmer and drier summer conditions were associated with higher fire frequency (Whitlock 1992; Walsh et al. 2008; Walsh et al. 2015).

Sediment charcoal analysis documented relatively frequent (across the paleoecological record) fire activity during the early Holocene in eight locations: North Cascade Range (Prichard et al. 2009), Olympic Peninsula (Gavin et al. 2013), Puget Lowlands (Crausbay et al. 2017), southwestern Washington (Walsh et al. 2008), Oregon Coast Range (Long et al. 1998), Willamette Valley (Walsh et al. 2010), Siskiyou Mountains (Briles 
Table 2 Risk assessment for the effects of fire-climate interactions in dry coniferous forest and woodlands, low to mid elevation (east-side Cascades, southern Idaho, drier areas of Rocky Mountains, USA), for the mid to late twenty-first century. Likelihood and confidence are rated low, moderate, and high. Low likelihood represents consequences that are unlikely (approximately 0 to 33\% probability), moderate likelihood represents consequences that are about as likely as not (approximately 33 to 66\% probability), high likelihood represents consequences that are likely to very likely (approximately 66 to 100\% probability). Low confidence is characterized by low scientific agreement and limited evidence, whereas high confidence is characterized by high scientific agreement and robust evidence, with moderate confidence falling between those two extremes

\begin{tabular}{llll}
\hline Fire-climate interaction & Magnitude of consequences & Likelihood of consequences & Confidence \\
\hline Wildfire frequency & Large increase & High & High \\
Wildfire extent & Large increase & High & High \\
Wildfire severity & Large increase in areas with elevated fuel loading & High & High \\
Reburns & Moderate increase & Moderate & Moderate \\
Stress interactions & Large increase & High & High \\
Regeneration & Low to high decrease, depending on site & Moderate & Moderate \\
\hline
\end{tabular}

et al. 2005), and Northern Rocky Mountains in Idaho (Brunelle and Whitlock 2003) (Table 4). Higher fire frequency in these locations was generally associated with higher abundance of tree species adapted to survive fire or regenerate soon after fire, including Douglas-fir, lodgepole pine, and Oregon white oak (Quercus garryana Douglas ex Hook.) (Table 4). Other pollen analyses (without parallel charcoal analysis) support the expansion of these species during the early Holocene (e.g., Sea and Whitlock 1995; Worona and Whitlock 1995), in addition to the expansion of ponderosa pine and oak in drier interior forests (Hansen 1943; Whitlock and Bartlein 1997). Relatively frequent fire (across the paleoecological record) during the early Holocene likely resulted in a mosaic of forest successional stages, with species such as red alder (Alnus rubra Bong.) dominating earlysuccessional stages in mesic forest types (Cwynar 1987).

Paleoecological studies (covering the early Holocene and other time periods) indicate that climate has been a major control on fire in the Northwest over millennia, with interactions between fire and vegetation. During times of high climatic variability and fire frequency (e.g., the early
Holocene), fires were catalysts for large-scale shifts in forest composition and structure (Prichard et al. 2009; Crausbay et al. 2017). Species that persisted during these times of rapid change have life history traits that facilitate survival in frequently disturbed environments (Brubaker 1988; Whitlock 1992), including red alder, Douglas-fir, lodgepole pine, ponderosa pine, and Oregon white oak, which suggests that these species may be successful in a warmer future climate (Whitlock 1992; Prichard et al. 2009).

\section{Fire-scar and tree-ring records}

Fire-scar studies indicate that climate was historically a primary determinant of fire frequency and extent in the Northwest. Years with increased fire frequency and area burned were generally associated with warmer and drier spring and summer conditions in the Northwest (Hessl et al. 2004; Wright and Agee 2004; Heyerdahl et al. 2008; Taylor et al. 2008). Climate of previous years does not have a demonstrated effect on fire, unlike other regions such as the Southwest, most likely because fuels are not as limiting for fire across the Northwest (Heyerdahl et al. 2002; Hessl et al. 2004).

Table 3 Risk assessment for the effects of fire-climate interactions in subalpine coniferous forest and woodland, high elevation (including aspen; all US Pacific Northwest mountain ranges), for the mid to late twenty-first century. Likelihood and confidence are rated low, moderate, and high. Low likelihood represents consequences that are unlikely (approximately 0 to 33\% probability), moderate likelihood represents consequences that are about as likely as not (approximately 33 to 66\% probability), high likelihood represents consequences that are likely to very likely (approximately 66 to 100\% probability). Low confidence is characterized by low scientific agreement and limited evidence, whereas high confidence is characterized by high scientific agreement and robust evidence, with moderate confidence falling between those two extremes

\begin{tabular}{llll}
\hline Fire-climate interaction & Magnitude of consequences & Likelihood of consequences & Confidence \\
\hline Wildfire frequency & Moderate increase & Moderate & High \\
Wildfire extent & Moderate increase & Moderate & Moderate \\
Wildfire severity & No change to small increase & Low & Moderate \\
Reburns & No change to small increase & Low & Moderate \\
Stress interactions & Small increase & Moderate & Moderate \\
Regeneration & Variable, depending on fire size & Moderate & Moderate \\
\hline
\end{tabular}


Table 4 Dominant tree species (current [late twentieth to early twenty-first century] and during the Early Holocene, circa 10500 to 5000 yr BP) in select locations in the Pacific Northwest, USA, where charcoal analysis indicated increased fire activity in the warmer and drier summers of the Early Holocene. Locations are listed from north to south. These studies were selected to cover a range of geographic locations and forest types and do not represent a comprehensive list of charcoal analyses for the Northwest. For a more comprehensive list, see Walsh et al. (2015)

\begin{tabular}{|c|c|c|c|c|c|}
\hline Region (site) & Elevation (m) & Latitude, longitude $\left(^{\circ}\right)$ & $\begin{array}{l}\text { Current dominant } \\
\text { tree species }^{\mathrm{a}}\end{array}$ & $\begin{array}{l}\text { Early Holocene dominant } \\
\text { tree species }^{\mathrm{a}}\end{array}$ & Reference \\
\hline $\begin{array}{l}\text { North Cascade Range, } \\
\text { Washington (Panther } \\
\text { Potholes) }\end{array}$ & 1100 & $48.658,-121.04$ & $\begin{array}{l}\text { Douglas-fir, Pacific } \\
\text { silver fir, western } \\
\text { hemlock, western } \\
\text { redcedar }\end{array}$ & Lodgepole pine & Prichard et al. 2009 \\
\hline $\begin{array}{l}\text { Puget Lowlands, } \\
\text { Washington (Marckworth } \\
\text { State Forest) }\end{array}$ & $\sim 430$ & $47.772,-121.811$ & $\begin{array}{l}\text { Douglas-fir, western } \\
\text { hemlock, western } \\
\text { redcedar }\end{array}$ & Douglas-fir & Crausbay et al. 2017 \\
\hline $\begin{array}{l}\text { Western Olympic } \\
\text { Peninsula, Washington } \\
\text { (Yahoo Lake) }\end{array}$ & 710 & $47.677,-124.018$ & $\begin{array}{l}\text { Pacific silver fir, } \\
\text { western hemlock, } \\
\text { western redcedar }\end{array}$ & $\begin{array}{l}\text { Douglas-fir, red alder, } \\
\text { Sitka spruce }\end{array}$ & Gavin et al. 2013 \\
\hline $\begin{array}{l}\text { Southwestern } \\
\text { Washington (Battle } \\
\text { Ground Lake) }\end{array}$ & 154 & $45.805,-122.494$ & $\begin{array}{l}\text { Douglas-fir, } \\
\text { western redcedar, } \\
\text { western hemlock, } \\
\text { grand fir, Sitka spruce }\end{array}$ & $\begin{array}{l}\text { Oregon white oak, } \\
\text { Douglas-fir }\end{array}$ & Walsh et al. 2008 \\
\hline $\begin{array}{l}\text { Northern Rocky } \\
\text { Mountains, Idaho } \\
\text { (Burnt Knob Lake) }\end{array}$ & 2250 & $45.704,-114.987$ & $\begin{array}{l}\text { Subalpine fir, whitebark } \\
\text { pine, lodgepole pine, } \\
\text { Engelmann spruce }\end{array}$ & $\begin{array}{l}\text { Douglas-fir, whitebark } \\
\text { pine, lodgepole pine }\end{array}$ & Brunelle and Whitlock 2003 \\
\hline $\begin{array}{l}\text { Willamette Valley, } \\
\text { Oregon (Beaver Lake) }\end{array}$ & 69 & $44.551,-123.17$ & $\begin{array}{l}\text { Willow, black } \\
\text { cottonwood, Oregon } \\
\text { ash, Oregon } \\
\text { white oak }\end{array}$ & $\begin{array}{l}\text { Oregon white oak, } \\
\text { Douglas-fir, beaked hazel, } \\
\text { bigleaf maple, red alder }\end{array}$ & Walsh et al. 2010 \\
\hline $\begin{array}{l}\text { Oregon Coast Range } \\
\text { (Little Lake) }\end{array}$ & 210 & $44.167^{\circ}-123.584$ & $\begin{array}{l}\text { Western hemlock, } \\
\text { Douglas-fir, western } \\
\text { redcedar, grand fir, } \\
\text { Sitka spruce }\end{array}$ & $\begin{array}{l}\text { Douglas-fir, red alder, } \\
\text { Oregon white oak }\end{array}$ & Long et al. 1998 \\
\hline $\begin{array}{l}\text { Siskiyou Mountains, } \\
\text { Oregon (Bolan Lake) }\end{array}$ & 1600 & $42.022,-123.459$ & White fir, Douglas-fir & $\begin{array}{l}\text { Western white pine, } \\
\text { sugar pine, Oregon } \\
\text { white oak, incense cedar }\end{array}$ & Briles et al. 2005 \\
\hline
\end{tabular}

${ }^{a}$ Species names that are not otherwise indicated in the text: beaked hazel (Corylus cornuta ssp. cornuta Marshall), bigleaf maple (Acer macrophyllum Pursh), black cottonwood, (Populus trichocarpa Torr. \& A. Gray ex Hook.), incense-cedar (Calocedrus decurrens [Torr.] Florin), Oregon ash (Fraxinus latifolia Benth.), Pacific silver fir (Abies amabilis Douglas ex J. Forbes), sugar pine (Pinus lambertiana Douglas), western redcedar (Thuja plicata Donn ex D. Don), western white pine (Pinus monticola Douglas ex D. Don.), willow (Salix spp. L.)

Warmer and drier conditions in winter and spring are more common during the El Niño phase of the El NiñoSouthern Oscillation (ENSO) in the Northwest (Mote et al. 2014). The Pacific Decadal Oscillation (PDO) is an ENSOlike pattern in the North Pacific, resulting in sea surface temperature patterns that appeared to occur in 20- to 30year phases during the twentieth century (Mantua et al. 1997). Positive phases of the PDO are associated with warmer and drier winter conditions in the Northwest.

Associations between large fire years and El Niño have been found in the interior Northwest (e.g., Heyerdahl et al. 2002), as have associations between large fire years and the (warm, dry) positive phase of the PDO (Hessl et al. 2004). Other studies have found ambiguous or non-significant relationships between fire and these climate cycles in the Northwest (e.g., Hessl et al. 2004; Taylor et al. 2008). However, interactions between ENSO and PDO (El Niño plus positive phase PDO) were associated with increased area burned (Westerling and Swetnam 2003) and synchronized fire in some years in dry forests across the inland Northwest (Heyerdahl et al. 2008).

The PDO and ENSO likely affect fire extent by influencing the length of the fire season (Heyerdahl et al. 2002). Warmer and drier winter and spring conditions increase the length of time that fuels are flammable (Wright and Agee 2004). Although climate change effects on the PDO and ENSO are uncertain, both modes of climatic variation influence winter and spring conditions in the Northwest, whereas summer drought during the year of a fire has the strongest association with major fire years at the site and regional scales (Hessl et al. 2004). Summer drought conditions are likely more important than in other regions where spring conditions are more strongly related to fire, because the Northwest has a winter- 
dominant precipitation regime; fire season occurs primarily in late summer (August through September), and summer drought reduces fuel moisture (Hessl et al. 2004; Littell et al. 2016).

\section{Contemporary climate and fire records}

In the twentieth century, wildfire area burned in the Northwest was positively related to low precipitation, drought, and temperature (Littell et al. 2009; Abatzoglou and Kolden 2013; Holden et al. 2018). Warmer spring and summer temperatures across the western United States cause early snowmelt, increased evapotranspiration, lower summer soil and fuel moisture, and thus longer fire seasons (Westerling 2016). Precipitation during the fire season also exerts a strong control on area burned through wetting effects and feedbacks to vapor pressure deficit (a measure of humidity; Holden et al. 2018). Between 2000 and 2015, warmer temperatures and vapor pressure deficit decreased fuel moisture during the fire season in $75 \%$ of the forested area in the western US and added about nine days per year of high fire potential (defined using several measures of fuel aridity; Abatzoglou and Williams 2016).

Periods of high annual area burned in the Northwest are also associated with high (upper atmosphere) blocking ridges over western North America and the North Pacific Ocean. Blocking ridges occur when centers of high pressure occur over a region in such a way that they prevent other weather systems from moving through. These blocking ridges, typical in the positive phase of the PDO (Trouet et al. 2006), divert moisture away from the region, increasing temperature and reducing relative humidity (Gedalof et al. 2005). Prolonged blocking and more severe drought (Brewer et al. 2012) are needed to dry out fuels in mesic to wet forest types (e.g., Sitka spruce [Picea sitchensis \{Bong.\} Carrière], western hemlock) along coastal Oregon and Washington. With increased concentrations of carbon dioxide in the atmosphere, the persistence of high blocking ridges that divert moisture from the region may increase (Lupo et al. 1997, as cited in Flannigan et al. 2009), further enhancing drought conditions and the potential for fire.

Lightning ignitions also affect wildfire frequency. However, research on lightning with recent and future climate change is equivocal. Some studies suggest that lightning will increase up to $40 \%$ globally in a warmer climate (Price and Rind 1994; Reeve and Toumi 1999; Romps et al. 2014), although a recent study suggests that lightning may decrease by as much as $15 \%$ globally (Finney et al. 2018).
Increases in annual area burned are generally associated with increases in area burned at high severity. Fire size, fire severity, and high-severity burn patch size were positively correlated in 125 fires in the North Cascades of Washington over a recent 25-year period (Cansler and McKenzie 2014). Other analyses have similarly shown a positive correlation between annual area burned and area burned severely (in large patches) in the Northwest (Dillon et al. 2011; Abatzoglou et al. 2017; Reilly et al. 2017). The annual extent of fire has increased slightly in the Northwest, although the proportion of area burning at high severity did not increase over the 1985 to 2010 period, either for the region as a whole or for any subregion (Reilly et al. 2017). Similarly, an analysis of recent fires (1984 to 2014) in the Northwest found no decrease in the proportion of unburned area within fire perimeters (Meddens et al. 2018).

Many studies have found that bottom-up controls such as vegetation, fuels, and topography are more important drivers of fire severity than climate in Western forests (e.g., Dillon et al. 2011; Parks et al. 2014). The direct influence of climate on fire severity is intrinsically much stronger in moister and higher-elevation forests, because drying of fuels in these systems requires extended warm and dry periods. Fire severity in many dry forest types is influenced primarily by fuel quantity and structure (Parks et al. 2014). However, fuel accumulations associated with fire exclusion in dry forests may be strengthening the influence of climate on fire severity, likely resulting in increased fire severity in drier forest types (Parks et al. 2016a).

\section{Wildfire projections under changing climate}

Historical patterns suggest that higher temperatures, stable or decreasing summer precipitation, and increased drought severity in the Northwest will likely increase the frequency and extent of fire. Models can help to explore potential future fire frequency and severity in a changing climate, with several types of models being used to project future fire (McKenzie et al. 2004). We focused here on models for which output is available in the Northwestempirical (statistical) models and mechanistic (processbased) models. Both types of models have limitations as well as strengths, but they are conceptually useful to assess potential changes in fire with climate change.

\section{Fire projections by empirical models}

Empirical models use the statistical relationship between observed climate and area burned during the historical record (the past 100 years or so) to project future area burned. Future area burned is based on projections of future temperature and precipitation, usually from global climate models. These models do not account for the 
potential decreases in burn probability in areas that have recently burned, or for long-term changes in vegetation (and thus flammability) with climate change (Parks et al. 2015; McKenzie and Littell 2017; Littell et al. 2018). They also do not account for human influence on fire ignitions (Syphard et al. 2017).

Numerous studies have developed empirical models to project future area burned or fire potential at both global (Krawchuk et al. 2009; Moritz et al. 2012) and regional scales (e.g., western US; McKenzie et al. 2004; Littell et al. 2010; Yue et al. 2013; Kitzberger et al. 2017). All studies suggest that fire potential, area burned, or both will increase in the western US in the future with warming climate. Below we highlight a few examples that explicitly address the Northwest. These examples provide future fire projections at relatively coarse spatial scales, with changes in area burned being variable across landscapes.

McKenzie et al. (2004) projected that, with a mean temperature increase of $2{ }^{\circ} \mathrm{C}$, area burned by wildfire will increase by a factor of 1.4 to 5 for most Western states, including Idaho, Montana, Oregon, and Washington. Kitzberger et al. (2017) projected increases in annual area burned of 5 times the median in 2010 to 2039 compared to 1961 to 2004 for the 11 conterminous Western states. Models developed by Littell et al. (2010) for Idaho, Montana, Oregon, and Washington suggested that area burned will double or triple by the 2080s, based on future climate projections for two global climate models (Fig. 4). Median area burned was projected to increase from about 0.2 million ha historically to 0.3 million ha in the 2020s, 0.5 million ha in the $2040 \mathrm{~s}$, and 0.8 million ha in the 2080s. The projections cited here are coarse scale, and area burned can be expected to vary from place to place within the area of the projections.

Littell et al. (2010) also developed empirical models at a finer (ecosection) scale for the state of Washington.
The relatively low frequency of fire in coastal forests makes development of empirical models difficult, so the output from these models for coastal forests is uncertain. For drier forest types, potential evapotranspiration and water balance deficit were the most important variables explaining area burned. In forested ecosystems (Western and Eastern Cascades, Okanogan Highlands, and Blue Mountains ecosections), the mean area burned was projected to increase by a factor of 3.8 in the 2040 s compared to 1980 to 2006. An updated version of these models, expanded to the western US (Littell et al. 2018), also suggests that area burned will increase in the future for most forested ecosections of the Northwest, but increases in area burned may be tempered, or area burned may decrease, in areas that are more fuel limited (e.g., in non-forest vegetation types).

Another application of empirical models is to project the future incidence of very large fires, often defined as the largest 5 to $10 \%$ of fires or fires $>5000$ ha. Barbero et al. (2015) projected that the annual probability of very large fires will increase by a factor of 4 in 2041 to 2070 compared to 1971 to 2000. Projections by Davis et al. (2017) suggested that the proportion of forests highly suitable for fires $>40$ ha will increase by $>20 \%$ in the next century for most of Oregon and Washington, but less so for the Coast Range and Puget Lowlands. The largest projected increases were in the Blue Mountains, Klamath Mountains, and East Cascades. The number of fires that escape initial attack will also likely increase (Fried et al. 2008).

Few empirical model projections are available for future fire severity. Using empirical models, Parks et al. (2016a) suggested that fire severity in a warming climate may not change significantly in the Northwest, because fuels limit fire severity. However, altered fire severity will depend partly on vegetation composition and structure (as they affect fuels), and climate change is expected to alter

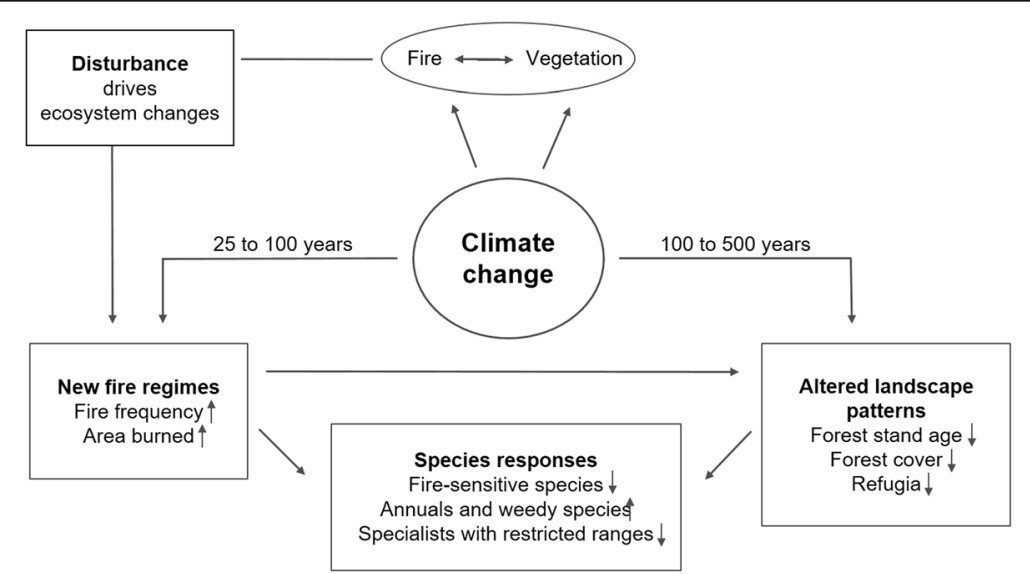

Fig. 4 Conceptual model showing that indirect effects of climate change via disturbance cause faster shifts in vegetation than do direct effects of climate change. Adapted from McKenzie et al. (2004) 
vegetation composition and structure both directly and indirectly (through disturbance). Empirical models do not account for these potential changes in vegetation and fuels (among other limitations; see McKenzie and Littell 2017). In the near term, high stem density as a result of fire exclusion and past management may increase fire severity in dry, historically frequent-fire forests (Haugo et al. 2019).

\section{Fire projections by mechanistic models}

Mechanistic models allow for exploration of potential interactions between vegetation and fire under changing and potentially novel climate. Mechanistic models can also account for elevated carbon dioxide concentration on vegetation, which could result in increased vegetation productivity (and fuel loading). Examples of mechanistic models that simulate fire include dynamic global vegetation models, such as MC1 (Bachelet et al. 2001), LANDIS-II (Scheller and Mladenoff 2008), and FireBioGeoChemical (Fire-BGC; Keane et al. 1996).

Using the $\mathrm{MC} 1$ dynamic global vegetation model for the western three quarters of Oregon and Washington, Rogers et al. (2011) projected a 76 to $310 \%$ increase in annual area burned and a 29 to $41 \%$ increase in burn severity (measured as aboveground carbon consumed by fire) by the end of the twenty-first century, with the degree of increase depending on climate scenario. These projected changes were largely driven by increased summer drought. Under a hot and dry climate scenario (with more frequent droughts), large fires were projected to occur throughout the twenty-first century (including the early part), primarily in mesic forests west of the Cascade crest.

Using the MC2 model (an updated version of MC1), Sheehan et al. (2015) also projected increasing fire activity in Idaho, Oregon, Washington, and western Montana. Mean fire return interval was projected to decrease across all forest-dominated subregions, with or without fire suppression. Projected decreases in mean fire interval were as high as $82 \%$ in the interior subregions without fire suppression; projected decreases in mean fire interval for the westernmost subregion were as high as $48 \%$ without fire suppression.

The MC1 and MC2 models have also been calibrated and run for smaller subregions in the Northwest. For the Willamette Valley, Turner et al. (2015) projected (under a high temperature increase scenario) increased fire frequency, with average area burned per year increasing by a factor of nine relative to the recent historical period (1986 to 2010); area burned over the recent historical period was very low $(0.2 \%$ of the area per year). For a western Washington study region, MC2 projected a $400 \%$ increase in annual area burned in the twenty-first century compared to 1980 to 2010 (Halofsky et al. 2018a). Although the projected average annual area burned was still only $1.2 \%$ of the landscape, some fire years were very large, burning 10 to $25 \%$ of the study region.

The MC1 model projected increased fire frequency and extent in forested lands east of the Cascade crest (Halofsky et al. 2013; Halofsky et al. 2014). Fire was projected to burn more than $75 \%$ of forested lands several times between 2070 and 2100 . On average, projected future fires burned the most forest under a hot, dry scenario. Applying the MC2 model to a larger south-central Oregon region, Case et al. (2019) suggested that future fire will become more frequent in most vegetation types, increasing most in dry and mesic forest types. For forested vegetation types, fire severity was projected to remain similar or increase slightly compared to historical fire severity.

The LANDIS-II model has been applied to the Oregon Coast Range in the Northwest. Creutzburg et al. (2017) found that area burned over the twenty-first century did not increase significantly with climate change compared to historical levels, but fire severity and extreme fire weather did increase.

Fire-BGC models have mostly been applied in the northern US Rocky Mountains, which overlaps with the Northwest. For northwestern Montana (Glacier National Park), Keane et al. (1999) used Fire-BGC in a warmer, wetter climate scenario to project higher vegetation productivity and fuel accumulations that contribute to more intense crown fires and larger fire sizes. Fire frequency also increased over a 250-year simulation period: fire rotation decreased from 276 to 213 years, and reburns occurred in $37 \%$ of the study area (compared to $17 \%$ under historical conditions). In drier locations (low-elevation south-facing sites), low-severity surface fires were more common, with fire return intervals of 50 years.

Mechanistic modeling suggests that fire frequency and area burned will increase in the Northwest. Fire severity may also increase, depending partly on forest composition, structure, and productivity over time. Warmer temperatures in winter and spring, and increased precipitation during the growing season (even early in the growing season), could increase forest productivity. This increase in productivity would maintain or increase fuel loadings and promote high-severity fires when drought and ignitions occur. In mechanistic model projections for the region, some of the largest increases in fire severity (Keane et al. 1999; Case et al. 2019) and the largest single fire years (Halofsky et al. 2013; Halofsky et al. 2018a) occurred in wetter scenarios with increased forest productivity. Future increased fire frequency without increased vegetation productivity is likely to result in decreased fire severity because of reduction in fuels as well as the potential for type conversion to vegetation 
characterized by less woody biomass. However, in highly productive systems such as forests west of the Cascade crest, future fires will probably be high severity (as they were historically) and more frequent (Rogers et al. 2011; Halofsky et al. 2018a).

\section{Short-interval reburns}

A reburn occurs when the perimeter of a recent past fire is breached by a subsequent fire, something that all fireprone forests have experienced. In the Northwest, reburns in the early twentieth century were documented in some of the earliest forestry publications (e.g., Isaac and Meagher 1936). However, under a warming climate, increased frequency and extent of fire will increase the likelihood of reburns, increasing the need to understand how earlier fires affect subsequent overlapping fires and how forests respond to multiple fires. Recent concern about reburns centers on projections that short-interval, high-severity (i.e., stand-replacing) reburns may become more common (Westerling et al. 2011; Prichard et al. 2017). Multiple fires can interact as linked disturbances (Simard et al. 2011), whereby the first fire affects the likelihood of occurrence, size, or magnitude (intensity, severity) of a reburn. Multiple fires can also interact to produce compound disturbance effects (Paine et al. 1998), in which ecological response after a reburn is qualitatively different than after the first fire.

\section{Effects of past fire on future fire occurrence}

Interactions between past forest fires and the occurrence of subsequent fires are generally characterized by negative feedbacks: fires are less likely to start within or spread into recently burned areas (i.e., within the last 5 to 25 years) compared to similar areas that have not experienced recent fire. For example, lightning-strike fires within the boundary of recently burned areas in the US Rocky Mountains (Idaho, Montana) were less likely to grow to fires larger than 20 ha than were lightning-strike fires in comparable areas outside recent fire boundaries (Parks et al. 2016b). This negative relation between past fires and likelihood of future fires is generally attributed to limits on ignition potential and initial spread of fires through fine woody fuels, which are sparse following fire. Fine fuels are consumed by the first fire and do not recover to sufficient levels until at least a decade later in many interior forest systems in the Northwest (Isaac 1940; Donato et al. 2013) and US Rocky Mountains (Nelson et al. 2016, 2017). However, negative feedbacks can be short-lived (or non-existent) in productive westside forests in the Northwest, where fuels are abundant in early-successional forests (Isaac 1940; Agee and Huff 1987; Gray and Franklin 1997).

Past fires in the northern US Rocky Mountains have also been effective at preventing the spread of subsequent fires into their perimeters (Teske et al. 2012; Parks et al. 2015). Similar results have been found in mixed-conifer forests of the interior Northwest, where past wildfire perimeters inhibited the spread of the 2007 Tripod Complex Fire in eastern Washington (Prichard and Kennedy 2014). This limitation of fire spread decreases with time. The probability that reburns will be inhibited by earlier fires is near $100 \%$ in the first year post fire, but is only $30 \%$ by 15 to 20 years post fire (Parks et al. 2015). However, extreme fire weather can dampen buffering effects of reburns at any interval between fires, such that past fire perimeters become less effective at inhibiting reburns during warm, dry, and windy conditions (Parks et al. 2015).

\section{Effects of past fire on future fire severity}

Fire severity (fire-caused vegetation mortality) in a reburn is affected by interactions among severity of the first fire, climate setting and forest type, interval between fires, and weather at the time of the reburn. Reburns are typically less severe when the interval between fires is shorter than 10 to 15 years (Parks et al. 2014; Harvey et al. 2016b; Stevens-Rumann et al. 2016). After 10 to 15 years, the effects of past fires on reburn severity diverge in different ecological contexts.

In areas where tree and shrub regeneration is prolific following one severe fire (e.g., moist Douglas-fir forests, subalpine forests dominated by lodgepole pine, some mixed-conifer forests [e.g., southwest Oregon mixed conifer forests with a hardwood component]), fire severity can be greater in reburns than in comparable single burns once the interval between fires exceeds 10 to 12 years (Thompson et al. 2007; Harvey et al. 2016b). In lower-elevation, drier, and more fuel-limited forests (e.g., ponderosa pine forests and woodlands, areas with slower woody plant establishment following fire), past fire limits future fire severity, often for 20 to 30 years (Parks et al. 2015; Harvey et al. 2016b; Stevens-Rumann et al. 2016). In these lower-productivity forests, the severity of past fire has been found to be the best predictor of reburn severity (Parks et al. 2014; Harvey et al. 2016b), but this is not necessarily the case in higher-productivity forests (Thompson et al. 2007; Stevens-Rumann et al. 2016). Surface fuel treatment followed by tree planting can greatly reduce the intensity of a reburn and allow most newly established trees to survive (Lyons-Tinsley and Peterson 2012).

Of particular concern for forest resilience is how and why forests may experience two severe fires in short succession. In the northern US Rocky Mountains, the likelihood of experiencing two successive stand-replacing fires (i.e., a severe fire followed by a severe reburn) is greatest (1) in areas with high post-fire regeneration capacity (e.g., higher-elevation subalpine forests on moist sites), and (2) when the reburn occurs during warm, dry 
conditions (Harvey et al. 2016b). In high-productivity west-side forests of Oregon and Washington, the potential for two successive high-severity burns may always exist (e.g., Isaac 1940), but occurrence depends on ignition and low fuel moisture.

\section{Effects of reburns on forest species composition and structure}

Short-interval reburns can produce compound effects on tree regeneration, altering species composition in some cases and shifting to non-forest vegetation in others. For example, thin-barked species, which do not survive fire but instead regenerate from seed following fire-induced mortality (e.g., lodgepole pine), can face "immaturity risk" if the interval between one fire and a reburn is too short to produce a sufficient canopy seedbank (Keeley et al. 1999; Turner et al. 2019). In northern US Rocky Mountain systems, lowand moderate-severity reburns have shifted dominance from lodgepole pine toward thick-barked species that can resist fire, such as ponderosa pine (Larson et al. 2013; Stevens-Rumann and Morgan 2016).

In the western Cascades of southern Washington, areas that burned in the 1902 Yacolt Burn and subsequently reburned within 30 years were characterized by much lower conifer regeneration than areas that burned only once (Gray and Franklin 1997). However, in the Klamath and Siskiyou mountains of southwestern Oregon, a short-interval (15 years between fires), highseverity reburn had no compound effect on regeneration (two years post fire) of Douglas-fir, the dominant tree species (Donato et al. 2009b), with no difference from areas that burned once at a longer interval $(>100$ years between fires). Plant species diversity and avian diversity were higher in reburns compared to once-burned areas, with hardwoods contributing to habitat diversity in the reburn areas (Donato et al. 2009b; Fontaine et al. 2009).

The effects of reburns on post-fire conifer regeneration seem to depend on legacy trees that survive both fires, providing seed across fire events (Donato et al. 2009b). In systems where legacy trees are rare (i.e., thinbarked species easily killed by fire) or where shrubs and hardwoods can outcompete trees for long durations, reburns are more likely to produce lasting compound effects on forest structure and composition, possibly resulting in a shift to non-forest vegetation.

\section{Disturbance and stress interactions}

Combinations of biotic and abiotic stressors, or stress complexes, will likely be major drivers of shifts in forest ecosystems with changing climate (Manion 1991). A warmer climate will affect forests directly through soil moisture stress and indirectly through increased extent and severity of disturbances, particularly fire and insect outbreaks (McKenzie et al. 2009).

\section{Water deficit and disturbance interactions}

Although water deficit (the condition in which potential summer atmospheric and plant demands exceed available soil moisture) is rarely fatal by itself, it is a predisposing factor that can exacerbate the forest stress complex (Manion 1991; McKenzie et al. 2009). Water deficit directly contributes to potentially lethal stresses in forest ecosystems by intensifying negative water balances (Stephenson 1998; Milne et al. 2002; Littell et al. 2008; Restaino et al. 2016). Water deficit also indirectly increases the frequency, extent, and severity of disturbances, especially wildfire and insect outbreaks (McKenzie et al. 2004; Logan and Powell 2009). These indirect disturbances alter forest ecosystem structure and function, at least temporarily, much faster than do chronic effects of water deficit (e.g., Loehman et al. 2017; Fig. 4).

\section{Interactions among drought, insect outbreaks, and fire}

During the past few decades, wildfires and insect outbreaks have affected a large area across the Northwest (Fig. 5). Increased area burned has been at least partly caused by extreme drought-wildfire dynamics, which will likely become more prominent as drought severity and area burned increase in the future (Parks et al. 2014; McKenzie and Littell 2017). Insect disturbance has likewise expanded across the Northwest since 1990, catalyzed by higher temperature and the prevalence of dense, low-vigor forests. Cambium feeders, such as bark beetles, are associated with prolonged droughts, in which tree defenses are compromised (Logan and Bentz 1999; Carroll et al. 2004; Hicke et al. 2006). Patches of fire-insect disturbance mosaic are starting to run into each other (Fig. 5), and similar to reburns, are an inevitable consequence of increasing disturbance activity, even in the absence of mechanistic links among disturbances.

In a review of the fire-bark beetle literature, Hicke et al. (2012) noted that, despite varying research approaches and questions, much agreement existed on fire hazard (defined as changes to fuels and potential fire behavior) after bark beetle outbreaks. There was strong agreement that surface fire and torching potential increased during the gray phase (e.g., 5 to 10 years following outbreaks, when snags remain standing; but see Woolley et al. 2019), but that crown fire potential was reduced in this phase. Similarly, there was agreement that fire hazard was lower in the old phase (i.e., silver phase), which occurs one to several decades after outbreak, when beetle-killed snags have fallen, understory vegetation increases, and seedlings establish. However, 


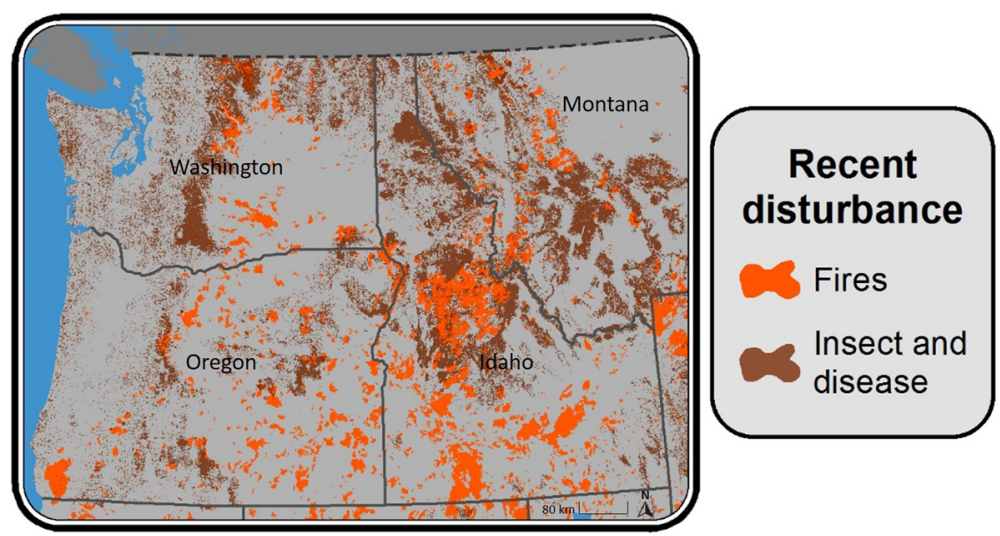

Fig. 5 Recent disturbances in the Northwest, USA, showing wildfire extent for 1984 to 2017 (orange), and insect and disease extent for 1997 to 2017 (brown). Data sources: Monitoring Trends in Burn Severity (https://www.mtbs.gov) and US Forest Service Insect and Disease Detection Survey (https://www.fs.fed.us/foresthealth/applied-sciences/mapping-reporting/gis-spatial-analysis/detection-surveys.shtml). Map credit: Robert Norheim

there was disagreement regarding fire potential during the red phase ( 0 to 4 years after outbreak initiation), when trees retain their drying needles and changes in foliar chemistry can increase flammability. Many studies have concluded that during this approximately 1 to 4-year period, fire hazard increases (Klutsch et al. 2011 [but see Simard et al. 2011], Hoffman et al. 2012, Jolly et al. 2012; Jenkins et al. 2014). Fire hazard has been found to increase as the proportion of the stand killed by bark beetles increases, regardless of forest type (Page and Jenkins 2007; DeRose and Long 2009; Hoffman et al. 2012).

Concern has also risen as to whether fire occurrence and severity will increase following outbreaks of bark beetles (e.g., Hoffman et al. 2013), although empirical support for such interactions has been lacking (Parker et al. 2006; Hicke et al. 2012). Insect outbreaks have not been shown to increase the likelihood of fire or area burned (Kulakowski and Jarvis 2011; Flower et al. 2014; Hart et al. 2015; Meigs et al. 2015). Further, when fire occurs in post-outbreak forests, most measures of fire severity related to firecaused vegetation mortality are generally similar between beetle-affected forests and areas that were unaffected by pre-fire outbreaks. Field studies in Oregon showed that burn severity (fire-caused vegetation mortality) was actually lower in lodgepole pine forests affected by mountain pine beetle (MPB; Dendroctonus ponderosae Hopkins) than analogous unaffected forests that burned (Agne et al. 2016). In an analysis of recent (1987 to 2011) fires across the Northwest, Meigs et al. (2016) also found that burn severity (from satellite-derived burn severity indices) was lower in forests with higher pre-fire insect outbreak severity.
Field studies in California, the Rocky Mountains, and interior British Columbia, Canada, conducted in a range of forest types have also explored the relationship between beetle outbreak severity (pre-fire basal area killed by beetles) and burn severity (fire-caused vegetation mortality), and suggest relatively minor effects of beetle outbreaks on burn severity. When fire burned through red stages ( 1 to 4 years post outbreak, when trees retain red needles) in dry conifer forests of California, small increases (e.g., 8 to $10 \%$ increase in fire-caused tree mortality) in burn severity were observed in areas of high outbreak severity (Stephens et al. 2018). In dry Douglas-fir forests in Wyoming, fire severity in the gray phase (4 to 10 years post outbreak) of Douglas-fir beetle (Dendroctonus pseudotsugae Hopkins) outbreak was unaffected by beetle outbreak severity (Harvey et al. 2013). Similar results of minimal beetle effect on fire severity were reported in gray-stage spruce-fir forests in Colorado, USA (Andrus et al. 2016). In lodgepole pine-dominated forests affected by MPB, outbreak effects on burn severity differed by weather and stage of outbreak. For example, in both green and red phases (when most beetle-killed trees retained crowns fading from green to red), fire severity increased with pre-fire beetle outbreak severity under moderate but not extreme (e.g., hot, dry, windy) weather (Harvey et al. 2014a). Conversely, in the red and gray stages, fire severity increased with pre-fire outbreak severity under extreme but not moderate weather (Harvey et al. 2014b).

In British Columbia, gray-stage post-outbreak stands did not burn more severely than unaffected stands for most measures of burn severity (Talucci et al. 2019). The effects of beetle outbreaks on fire severity in forest types typified by stand-replacing fire regimes seem to be overall variable and minor, especially given that such forest types are inherently characterized by severe fire. 
The key exception to the otherwise modest effects of prefire beetle outbreaks on burn severity is the effect of deep wood charring and combustion on beetle-killed snags that burn. This effect has been reported across stages and forest type when measured, and consistently increases with pre-fire beetle outbreak severity (Harvey et al. 2014b; Talucci et al. 2019). Because fire intensity and thus severity are driven by topography, weather, and fuels, beetleoutbreak-induced changes to fuel structures may play a minor role in affecting fire severity. In all cases in studies above where topography and weather were quantified, fire severity responded strongly and consistently to these factors irrespective of pre-fire beetle outbreaks.

In the Northwest, lodgepole pine forests have been affected by MPB outbreaks, with high mortality in some locations (e.g., Okanogan-Wenatchee Forest; Fig. 6). Widely distributed at mid to higher elevations in the Rocky Mountains, lodgepole pine is the dominant species over much of its range there, forming nearly monospecific stands. In the Northwest, lodgepole pine occurs at mid to higher elevations in the Cascade Range and eastward, and monospecific stands are limited to early seral stages and specific soil conditions (e.g., Pumice Plateau in central Oregon). In some populations in the Northwest, lodgepole pine forests have also adapted to stand-replacing fires via cone serotiny.

Bark beetle outbreaks and subsequent fire may interact to affect post-fire forest recovery, but results differ depending on the dominant regeneration mechanism of the tree attacked by beetles. Species with a persistent canopy seedbank, such as lodgepole pine, are minimally affected by compound disturbances between beetle outbreaks and fire. For example, in the Cascade Range and Rocky Mountains, areas that experienced beetle outbreaks prior to fire had similar levels of post-fire lodgepole pine seedling establishment compared to areas that had fire only (Harvey et al. 2014a; Harvey et al. 2014b; Edwards et al. 2015; Agne et al. 2016). Species such as Douglas-fir, which do not have a persistent canopy seedbank, have been shown to have lower post-fire seedling establishment in areas affected by Douglas-fir beetle outbreaks and fire (Harvey et al. 2013), although effects may be transient and disappear with time since fire (Stevens-Rumann et al. 2015).

\section{Interactions among fungal pathogens and other stressors}

The effects of weather and climate on fungal pathogens vary by species, with the spread of some pathogens facilitated by drought and others by wet periods (Klopfenstein et al. 2009; Sturrock et al. 2011; Ayres et al. 2014). Forests with low vigor and physiologically stressed trees (e.g., dense stands) are generally more susceptible to fungal pathogens. In the Northwest, a wide range of root rots and other native fungal pathogens exists in all forest types. For example, on the west side of the Cascade Range, laminated root rot (Phellinus weirii [Murrill] Gilb.) is widespread, causing small pockets of mortality in Douglas-fir (Agne et al. 2018). However, no evidence exists that this pathogen has been or will be accelerated by a warmer climate. Other pathogens, such as Swiss needle cast (Phaeocryptopus gaeumannii [T. Rohde] Petrak), may be favored by warmer and wetter winters (Agne et al. 2018). Fungal pathogens stress trees and may increase susceptibility to insect infestations. For example, Douglas-fir beetle is closely associated with laminated root rot centers in forests on the west side of the Cascades in Oregon and Washington (Goheen and Hansen 1993). Overall, interactions between fungal pathogens and fire with climate change are uncertain.

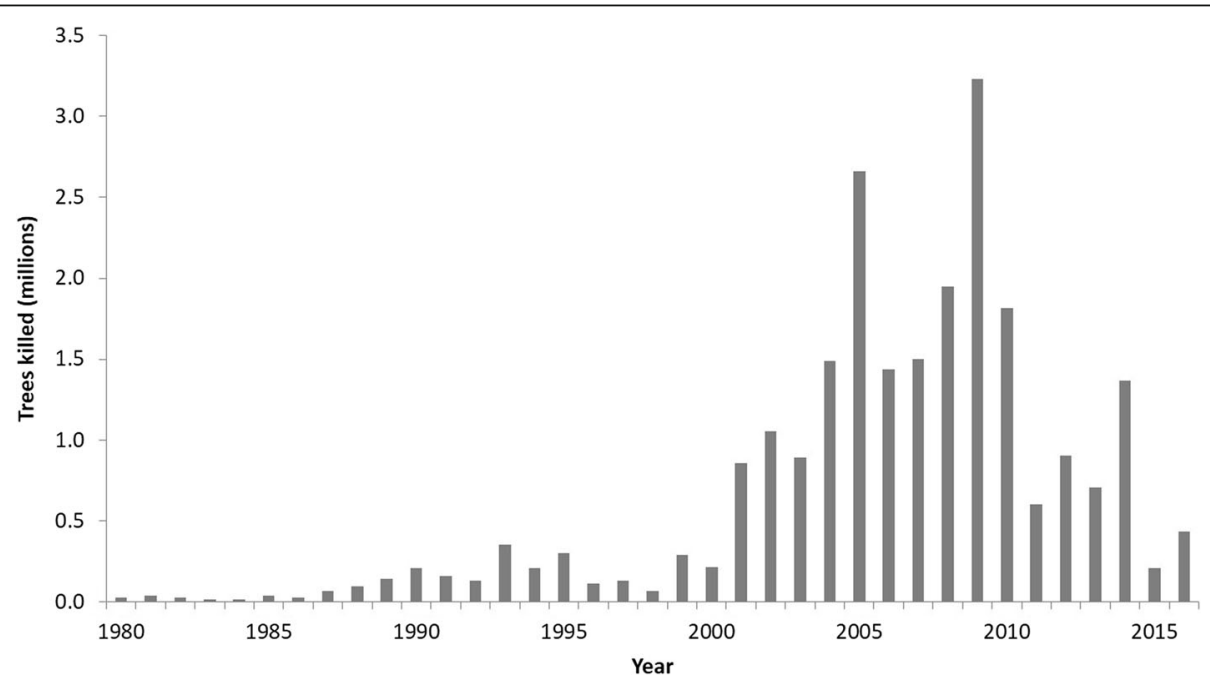

Fig. 6 Number of trees killed by beetles in Okanogan-Wenatchee National Forest, Washington, USA, from 1980 to 2016. Data source: C. Mehmel, Okanogan-Wenatchee National Forest, Washington, USA 


\section{Stress complexes and forest mortality}

Recent large-scale tree mortality events in the Southwest (Breshears et al. 2005), Texas (Schwantes et al. 2016), and California, USA (Young et al. 2017), have been caused by multi-year droughts weakening trees, followed by various beetle species acting as the mortality agents. It is likely that more intense and longer droughts will increase in the future under changing climate (Trenberth et al. 2014), and interactions between drought and other disturbance agents are likely to cause tree mortality. As noted above, fungal pathogens may contribute to increasing insect outbreaks (Goheen and Hansen 1993), along with increasing temperatures, shorter winters, and tree stress. Fire-caused tree mortality will also likely be affected by interacting disturbances. In some cases, fire severity has been marginally higher in areas affected by beetle mortality (Harvey et al. 2014a; Harvey et al. 2014b; Stephens et al. 2018). However, empirical studies examining the effects of large-scale tree mortality events on fire behavior are limited (Stephens et al. 2018). Modeling studies suggest that fire rate of spread may increase after mortality events (e.g., Perrakis et al. 2014).

\section{Effects of changing disturbance regimes on forest structure and composition}

In Northwest forest ecosystems, warming climate and changing disturbance regimes are likely to lead to changes in species composition and structure, probably over many decades. In general, increased fire frequency will favor plant species with life history traits that allow for survival with more frequent fire (Chmura et al. 2011). These include (1) species that can resist fires (e.g., thick-barked species such as Douglas-fir, western larch [Larix laricina Nutt.], and ponderosa pine); (2) species with high dispersal ability that can establish after fires (e.g., Douglas-fir); and (3) species with serotinous cones that allow seed dispersal from the canopy after fire (e.g., lodgepole pine) (Rowe 1983; Agee 1993).

In the forest understory, increased fire frequency and extent will likely create more opportunities for establishment by invasive species (Hellmann et al. 2008). Species that can endure fires (sprouters) and seedbank species (evaders) are also likely to increase with more frequent fire. For example, sprouting shrubs and hardwoods are prolific after fire in southwest Oregon (Halofsky et al. 2011). However, high-intensity fire can consume or kill seeds stored in the upper soil layers and kill shallow belowground plant parts, and repeated fires at short intervals can deplete seed stores and belowground plant resources (Zedler et al. 1983).

More frequent fire will likely decrease abundance of avoider species, including shade-tolerant species, species with thin bark, and slow invaders after fire (Chmura et al. 2011). Forest stands composed primarily of fire-susceptible evader species, such as western hemlock, subalpine fir, and Engelmann spruce (Picea engelmannii Parry ex Engelm.), will likely have higher mortality for a given fire intensity than stands composed of more fire-resistant species, such as mature Douglas-fir and western larch. If fire-sensitive species are not able to re-seed into burned areas and reestablish themselves (because of short fire intervals, competition, or harsh conditions for seedling establishment), these species can be lost from a site (Stevens-Rumann and Morgan 2016). Direct mortality or lack of regeneration of firesensitive species with more frequent fire will favor more fire-adapted species that can survive fire or regenerate after fire. For example, in southwest Oregon, shrubs and hardwoods are likely to increase in abundance with increased fire frequency and reduced conifer regeneration in some locations (Tepley et al. 2017).

Changes in disturbance regimes can influence the structure of forests at multiple spatial scales (Reilly et al. 2018). Within forest stands, more frequent fire will likely decrease tree density in dry forests, and open savannas may increase in area. Forest understories may shift from being duff- or forb-dominated to shrub- or grassdominated. Tree canopy base heights will likely increase as frequent fires remove lower branches. Across forested landscapes (i.e., among stands), fire directly influences the spatial mosaic of forest patches (Agee 1993). More extreme fire conditions with climate change may initially lead to larger and more frequent fires, resulting in larger burn patch sizes and greater landscape homogeneity (Harvey et al. 2016a). More frequent severe fire will likely decrease forest age, the fraction of old-growth forest patches, and the landscape connectivity of oldgrowth forest patches (Baker 1995; McKenzie et al. 2004). However, more frequent low- and mixed-severity fires may eventually reduce fuels in drier forest ecosystems (e.g., dry mixed conifer), leading to lower-intensity fires and a finer-scale patch mosaic (Chmura et al. 2011).

\section{Effects of climate change on post-fire processes Forest regeneration}

Changing climate and fire frequency, extent, and severity are likely to influence forest regeneration processes, thus affecting the structural and compositional trajectories of forest ecosystems. First, climate change is expected to affect regeneration through increased fire frequency. As fire-free intervals shorten, the time available for plants to mature and produce seed before the next fire will be limited. Such changes in fire-free intervals can have significant effects on post-fire regeneration, because different plants have varied adaptations to fire. Species that resprout following fire may decline in density, but species that are fire-killed and thus require reproduction from seed may be locally eliminated.

Second, climate change may result in increased fire severity. If the size of high-severity fire patches increases, 
seed sources to regenerate these patches will be limited. Regeneration of non-serotinous species will require long-distance seed dispersal and may be slower in large, high-severity patches (Little et al. 1994; Donato et al. 2009a; Downing et al. 2019).

Third, climate change will likely result in increased forest drought stress. Warmer temperatures, lower snowpack, and increased evapotranspiration will increase summer drought stress. Warmer and drier conditions after fire events may cause recruitment failures, particularly at the seedling stage (Dodson and Root 2013). In this way, fire can accelerate species turnover when climatic conditions are unfavorable for establishment of dominant species (Crausbay et al. 2017) and seed sources are available for alternative species.

Regeneration in dry forests in the Northwest (e.g., ponderosa pine) may be particularly sensitive to changing climate. Hotter and drier sites (e.g., on southwestern aspects) may be particularly at risk for regeneration failures (Nitschke et al. 2012; Dodson and Root 2013; Donato et al. 2016; Rother and Veblen 2017; Tepley et al. 2017). High soil surface temperatures can also cause mortality (Minore and Laacke 1992). Forest structure (mainly shade from an existing canopy) can ameliorate harsh conditions and allow for regeneration (Dobrowski et al. 2015). However, after high-severity disturbance, dry forests at the warm and dry edges of their distribution (ecotones) may convert to grasslands or shrublands in a warming climate (Johnstone et al. 2010; Jiang et al. 2013; Savage et al. 2013; Donato et al. 2016; Stevens-Rumann et al. 2017).

In the Klamath-Siskiyou ecoregion of southwestern Oregon and northern California, Tepley et al. (2017) found that conifer regeneration was reduced by low soil moisture after fires. With lower soil moisture, greater propagule pressure (smaller high-severity patches with more live seed trees) was needed to achieve a given level of regeneration. This suggests that, at high levels of climatic water deficit, even small high-severity patches are at risk for low post-fire conifer regeneration. Successive fires could further limit conifer seed sources, thus favoring shrubs and hardwoods.

Germination of ponderosa pine is favored by moderate temperatures and low moisture stress, and survival increases when maximum temperatures are warm (but not hot) and when growing season rainfall is above average (Petrie et al. 2016; Rother and Veblen 2017). Empirical modeling by Petrie et al. (2017) projected that, with warming temperature in the middle of the twenty-first century, regeneration potential of ponderosa pine may increase slightly on many sites. However, by the end of the century, with decreased moisture availability, regeneration potential in the Northwest decreased by $67 \%$ in 2060 to 2099 compared to 1910 to 2014. In the eastern Cascade Range of Oregon, Dodson and Root (2013) found decreasing ponderosa pine regeneration with decreasing elevation and moisture availability, suggesting that moisture stress would limit regeneration.

Several studies in the Rocky Mountains have also found decreased post-fire regeneration with increased water deficits on drier, lower-elevation sites (Rother et al. 2015; Donato et al. 2016; Stevens-Rumann et al. 2017; Davis et al. 2019). Donato et al. (2016) found decreased regeneration of Douglas-fir 24 years after fire on drier, lower-elevation sites compared to more mesic sites at higher elevations. Regeneration declined with higher burn severity and was minimal beyond 100 to $200 \mathrm{~m}$ from a seed source. Similarly, Harvey et al. (2016c) found that post-fire tree seedling establishment decreased with greater post-fire drought severity in subalpine forests of the northern US Rocky Mountains; post-fire subalpine fir and Engelmann spruce regeneration were both negatively affected by drought. Davis et al. (2019) modeled post-fire recruitment probability for ponderosa pine and Douglas-fir on sites in the Rocky Mountains, and found that recruitment probability decreased between 1988 and 2015 for both species, suggesting a decline in climatic suitability for post-fire tree regeneration.

In a study of annual regeneration and growth for 10 years following wildfire in the eastern Cascade Range of Washington, Littlefield (2019) found that establishment rates of lodgepole pine (and other species) were highest when growing seasons were cool and moist. A lagged climate signal was apparent in annual growth rates, but standardized climate-growth relationships did not vary across topographic settings, suggesting that topographic setting did not decouple site conditions from broader climatic trends to a degree that affected growth patterns. These results underscore the importance of favorable post-fire climatic conditions in promoting robust establishment and growth while highlighting the importance of topography and stand-scale processes (e.g., seed availability and delivery). Although concerns about post-fire regeneration failure may be warranted under some conditions, failure is not a general phenomenon in all places and at all times (Littlefield 2019).

If warming climate trends continue as projected, without (or even with) tree planting, loss of forests may occur on the driest sites in the Northwest (Donato et al. 2016; Harvey et al. 2016c; Stevens-Rumann et al. 2017), particularly east of the Cascade crest and in southwestern Oregon. Individual drought years are not likely to alter post-fire successional pathways, especially if wet years occur between dry years (Tepley et al. 2017; Littlefield 2019). Recruitment of conifers following a disturbance can require years to decades in the Northwest (Little et al. 1994; Shatford et al. 2007; Tepley et al. 2014). Thus, shrubs or grasses may dominate during drought periods, but conifers could establish and overtop shrubs and grasses during wetter and cooler periods (Dugan and Baker 2015; Donato et al. 2016). 


\section{Management actions}

More frequent and larger wildfires in Northwest forests will likely be a major challenge facing resource managers of public and private lands in future decades (Peterson et al. 2011a). Adapting forest management to climate change will help forest ecosystems transition to new conditions, while continuing to provide timber, water, recreation, habitat, and other benefits to society. Starting the process of adaptation now, before the marked increase in wildfire expected by the mid twenty-first century, will likely improve options for successful outcomes. Fortunately, some current forest management practices, including stand density management and surface fuel reduction in dry forests, and control of invasive species, are "climate smart" because they increase resilience to changing climate and disturbances (Peterson et al. 2011a; Peterson et al. 2011b).

Resource managers will likely be unable to prevent increasing broad-scale trends in area burned with climate change, but fuel treatments can decrease fire intensity and severity locally (Agee and Skinner 2005; Peterson et al. 2005). In drought- and fire-prone forests of the Northwest (e.g., ponderosa pine and dry mixed-conifer forests east of the Cascades and in southwestern Oregon), reducing forest density can decrease crown fire potential (Agee and Skinner 2005; Safford et al. 2012; Martinson and Omi 2013; Shive et al. 2013), and negative effects of drought on tree growth (Clark et al. 2016; Sohn et al. 2016). Even in wetter forest types, reducing stand density can increase water availability, tree growth, and tree vigor by reducing competition (Roberts and Harrington 2008). Decreases in forest stand density, coupled with hazardous fuel treatments, can also increase forest resilience to wildfire in dry forest types (Agee and Skinner 2005; Stephens et al. 2013; Hessburg et al. 2015).

In dry forests, forest thinning prescriptions may need to reduce forest density to increase forest resistance and resilience to fire, insects, and drought (Peterson et al. 2011a; Sohn et al. 2016). For example, in anticipation of a warmer climate and increased fire frequency, managers in Okanogan-Wenatchee National Forest in eastern Washington are currently basing stocking levels for thinning and fuel treatments on the next driest forest type. Thinning and fuel treatments could also be prioritized in (1) locations where climate change effects, particularly increased summer drought, are expected to be most pronounced (e.g., on south-facing slopes); (2) high-value habitats; and (3) high-risk locations such as the wildland-urban interface. Fuel treatments must be maintained over time to remain effective (Agee and Skinner 2005; Peterson et al. 2005). Insufficient financial resources, agency capacity constraints, and air quality constraints on prescribed burning are harsh realities that will in most cases limit the extent of fuel treatments
(Melvin 2018), necessitating strategic implementation of treatments in locations where fuel reduction will maximize ecological, economic, and political benefits.

Fewer options exist for reducing fire severity in wetter, high-elevation and coastal forests of the Northwest, historically characterized by infrequent, stand-replacement fire regimes (Halofsky et al. 2018b). In these ecosystems, thinning and hazardous fuel treatments are unlikely to significantly affect fire behavior, because fires typically occur under extreme weather conditions (i.e., during severe drought). However, managers may consider installing fuel breaks around high-value resources, such as municipal watersheds, key wildlife habitats, and valuable infrastructure, to reduce fire intensity and facilitate fire suppression efforts (Syphard et al. 2011). In addition, ecosystem resilience to a warmer climate is likely to improve by promoting landscape heterogeneity with diverse species and stand structures, and by reducing the effects of existing non-climatic stressors on ecosystems, such as landscape fragmentation and invasive species (Halofsky et al. 2018b).

The future increase in fire will put late-successional forest at risk, potentially reducing habitat structures (large trees, snags, downed wood) that are important for many plant and animal species. In dry forests, some structures can be protected from fire by thinning around them and reducing organic material at their base (Halofsky et al. 2016). To increase habitat quality and connectivity, increasing the density of these structures may be particularly effective in younger forests, especially where young forests are in close proximity to late-successional forest.

Regeneration failures after fire are a risk with changing climate, particularly for drier forests. A primary method to help increase natural post-fire regeneration is to increase seed sources by both reducing fire severity (through fuel treatments and prescribed fire) and increasing the number of live residual trees (Dodson and Root 2013). In areas adjacent to green trees, natural regeneration may be adequate. In locations farther than $200 \mathrm{~m}$ from living trees, managers may want to supplement natural regeneration with planting where costs are not prohibitive because of remoteness or topography (North et al. 2019). Where post-fire planting is desirable, managers may consider changes from current practices. For example, they may want to consider lowering stocking density and increasing the spatial heterogeneity of plantings to increase resilience to fire and drought (North et al. 2019). Planting seedlings on cooler, wetter microsites will also likely help to increase survival (Rother et al. 2015). Managers may also consider different genetic stock than has been used in the past to increase seedling survival (Chmura et al. 2011). Tools such as the Seedlot Selection Tool (https://seedlotselectiontool.org/sst) can help identify seedling stock that will be best adapted to a given site in the future. 
In general, regeneration in the driest topographic locations may be slower in a warming climate than it has been in the past. Some areas are likely to convert from conifer forest to hardwoods or non-forest (shrubland or grassland) vegetation, particularly at lower treeline. Managers may need to consider where they will try to forestall change and where they may need to allow conversions to occur (Rother et al. 2015).

Finally, collaboration among many groups-land management agencies, rural communities, private forest landowners, tribes, and conservation groups-is needed for successful adaptation to the effects of a warmer climate on wildfire (Joyce et al. 2009; Spies et al. 2010; Stein et al. 2013). Working together will ensure a common vision for stewardship of forest resources, and help produce a consistent, effective strategy for fuel treatments and other forest practices across large forest landscapes.

\section{Uncertainties and future research needs}

Changing disturbance regimes will accompany climate change in the Northwest (Tables 1, 2 and 3). However, uncertainties remain, many related to future human behavior relative to greenhouse gas emissions, the rate and magnitude of climate change, and effects on vegetation and fire regimes. Human activities will also affect fire through land use and management, fire ignitions, and fire suppression, all of which are difficult to predict. For example, societal priorities may change, affecting forest management and vegetation conditions. Fire suppression is likely to continue in the future, but may become less effective under more extreme fire weather conditions (Fried et al. 2008), affecting area burned.

Historical relationships between climate and fire in the Northwest indicate that the ENSO and PDO can influence area burned. However, it is unclear how climate change will affect these modes of climatic variability or how they may interact with the effects of climate change on natural resources; global climate models differ in how these cycles are represented and in how they are projected to change. The frequency and persistence of high blocking ridges in summer (which divert moisture from the region) will also affect fire frequency and severity in the region, and climate change may affect the frequency of these blocking ridges (Lupo et al. 1997).

The lack of fire over the last few centuries in forests with low-frequency and high-severity fire regimes creates uncertainty in fire projections for the future. Although the likelihood of a large fire event in these forests is low, if large fire events start occurring as frequently as some models project (e.g., Rogers et al. 2011), then major ecological changes are likely. Updating models as events occur over time may help to adjust projections in the future.

Shifts in forest productivity and composition are highly likely to occur with climate change in the region, which could affect fuel levels. However, it is uncertain how carbon dioxide fertilization will interact with moisture stress and disturbance regimes to affect forest productivity (Chmura et al. 2011) and thus fuel levels. Increased forest productivity, combined with hot and dry conditions in late summer, would likely produce large and severe fires (Rogers et al. 2011). Continued research on the potential effects of carbon dioxide fertilization on forest productivity will help to improve fire severity projections.

Other high-priority research needs include determining forest ecosystem response to multiple disturbances and stressors (e.g., effects of repeated fire and drought on forest regeneration), and determining post-fire regeneration controls across a range of forest types and conditions. Identifying locations where vegetation type shifts (e.g., forest to woodland or shrubland) are likely because of changing climate and disturbance regimes will help managers determine where to prioritize efforts. Managers will also benefit from evaluation of pre- and postfire forest treatments to increase resilience or facilitate transition to new conditions in different forest types.

Although this synthesis is focused on the effects of climate change on fire and vegetation, many secondary effects are expected for natural resources and ecosystem services, some of which are already occurring. Climate change is reducing snowpack (Mote et al. 2018) and affecting hydrologic function in the Northwest, including more flooding in winter and lower streamflow in summer (Luce and Holden 2009). Higher stream temperatures are degrading cold-water fish habitat (Isaak et al. 2010). Altered vegetation and snowpack are expected to have long-term implications for animal habitat (Singleton et al. 2019). Recreational opportunities (Hand et al. 2019), infrastructure on public lands (Furniss et al. 2018), and cultural values (Davis 2018) will likely also be affected by changing climate, fire, and other disturbances.

Uncertainties associated with climate change require an experimental approach to resource management; using an adaptive management framework can help address uncertainties and adjust management over time. In the context of climate change adaptation, adaptive management involves: (1) defining management goals, objectives, and timeframes; (2) analyzing vulnerabilities and determining priorities; (3) developing adaptation options; (4) implementing plans and projects; and (5) monitoring, reviewing, and adjusting (Millar et al. 2014). Scientists and managers can work together to implement an adaptive management framework and ensure that the best available science is used to inform management actions on the ground.

\section{Acknowledgements}

We thank D. Donato, L. Evers, B. Glenn, M. Johnson, V. Kane, M. Reilly, and three anonymous reviewers for providing helpful suggestions that improved the manuscript. P. Loesche provided valuable editorial assistance, J. Ho assisted with literature compilation and figures, and R. Norheim developed several maps. 


\section{Authors' contributions}

$\mathrm{JH}$ led the study and contributed to information collection, analysis, and interpretation, and co-wrote the paper. DP contributed to information collection, analysis, and interpretation, and co-wrote the paper. $\mathrm{BH}$ contributed to information collection, analysis, and interpretation, and cowrote the paper. All authors read and approved the final manuscript.

\section{Authors' information}

J. Halofsky is a research ecologist; D. Peterson is a professor of forest biology; B. Harvey is an assistant professor of forest ecology.

\section{Funding}

Funding was provided by the US Department of the Interior, Northwest Climate Adaptation Science Center, and the US Forest Service Pacific Northwest Research Station and Office of Sustainability and Climate. None of the funding bodies played any role in the design of the study, interpretation of data, or writing the manuscript.

\section{Availability of data and materials}

Please contact the corresponding author for data requests.

\section{Ethics approval and consent to participate}

Not applicable.

\section{Consent for publication}

Not applicable.

\section{Competing interests}

The authors declare that they have no competing interests.

\section{Author details}

'US Department of Agriculture, Forest Service, Pacific Northwest Research Station, Olympia Forestry Sciences Lab, 3625 93rd Avenue SW, Olympia, Washington 98512, USA. ${ }^{2}$ School of Environmental and Forest Sciences, College of the Environment, University of Washington, Box 352100, Seattle, Washington 98195-2100, USA.

\section{Received: 20 March 2019 Accepted: 11 November 2019}

\section{Published online: 27 January 2020}

\section{References}

Abatzoglou, J.T., and C.A. Kolden. 2013. Relationships between climate and macroscale area burned in the western United States. International Journal of Wildland Fire 22: 1003-1020 https://doi.org/10.1071/WF13019.

Abatzoglou, J.T., C.A. Kolden, A.P. Williams, J.A. Lutz, and A.M. Smith. 2017. Climatic influences on interannual variability in regional burn severity across western US forests. International Journal of Wildland Fire 26: 269-275 https:// doi.org/10.1071/WF16165.

Abatzoglou, J.T., and A.P. Williams. 2016. Impact of anthropogenic climate change on wildfire across western US forests. Proceedings of the National Academy of Sciences, USA 113: 11770-11775 https://doi.org/10.1073/pnas. 1607171113.

Agee, J.K. 1993. Fire ecology of Pacific Northwest forests. Washington, D.C.: Island Press.

Agee, J.K., and M.H. Huff. 1987. Fuel succession in a western hemlock/Douglas-fir forest. Canadian Journal of Forest Research 17: 697-704 https://doi.org/10. 1139/x87-112.

Agee, J.K., and C.N. Skinner. 2005. Basic principles of forest fuel reduction treatments. Forest Ecology and Management 211: 83-96 https://doi.org/10. 1016/j.foreco.2005.01.034.

Agne, M.C., P.A. Beedlow, D.C. Shaw, D.R. Woodruff, E.H. Lee, S.P. Cline, and R.L. Comeleo. 2018. Interactions of predominant insects and diseases with climate change in Douglas-fir forests of western Oregon and Washington, USA. Forest Ecology and Management 409: 317-332 https://doi.org/10.1016/j. foreco.2017.11.004.

Agne, M.C., T. Woolley, and S. Fitzgerald. 2016. Fire severity and cumulative disturbance effects in the post-mountain pine beetle lodgepole pine forests of the Pole Creek Fire. Forest Ecology and Management 366: 73-86 https:// doi.org/10.1016/j.foreco.2016.02.004.
Andrus, R.A., T.T. Veblen, B.J. Harvey, and S.J. Hart. 2016. Fire severity unaffected by spruce beetle outbreak in spruce-fir forests in southwestern Colorado. Ecological Applications 26: 700-711 https://doi.org/10.1890/15-1121.

Ayres, M.P., J.A. Hicke, B.K. Kerns, D. McKenzie, J.S. Littell, L.E. Band, C.H. Luce, A.S. Weed, and C.L. Raymond. 2014. Disturbance regimes and stressors. In Climate change and United States forests, ed. D.L. Peterson, J.M. Vose, and T. Patel-Weynand, 55-92. Dordrecht, The Netherlands: Springer https://doi. org/10.1007/978-94-007-7515-2_4.

Bachelet, D., J.M. Lenihan, C. Daly, R.P. Neilson, D.S. Ojima, and W.J. Parton. 2001 MC1: dynamic vegetation model for estimating the distribution of vegetation and associated ecosystem fluxes of carbon, nutrients, and water. USDA Forest Service General Technical Report PNW-GTR-508. Portland, Oregon, USA: USDA Forest Service, Pacific Northwest Research Station https://doi.org/10.2737/ PNW-GTR-508.

Baker, W.L. 1995. Longterm response of disturbance landscapes to human intervention and global change. Landscape Ecology 10: 143-159 https://doi. org/10.1007/BF00133028.

Barbero, R., J.T. Abatzoglou, N.K. Larkin, C.A. Kolden, and B. Stocks. 2015. Climate change presents increased potential for very large fires in the contiguous United States. International Journal of Wildland Fire 24: 892-899 https://doi. org/10.1071/WF15083.

Breshears, D.D., N.S. Cobb, P.M. Rich, K.P. Price, C.D. Allen, R.G. Balice, W.H. Romme, J. H. Kastens, M.L. Floyd, J. Belnap, J.J. Anderson, O.B. Myers, and C.W. Meyer. 2005. Regional vegetation die-off in response to global-change-type drought. Proceedings of the National Academy of Sciences, USA 102: 15144-15148 https:// doi.org/10.1073/pnas.0505734102.

Brewer, M.C., C.F. Mass, and B.E. Potter. 2012. The West Coast thermal trough: climatology and synoptic evolution. Monthly Weather Review 140: 3820-3843 https://doi.org/10.1175/MWR-D-12-00078.1.

Briles, C.E., C. Whitlock, and P.J. Bartlein. 2005. Postglacial vegetation, fire, and climate history of the Siskiyou Mountains, Oregon, USA. Quaternary Research 64: 44-56 https://doi.org/10.1016/j.yqres.2005.03.001.

Brubaker, L.B. 1988. Vegetation history and anticipating future vegetation change. In Ecosystem management for parks and wilderness, ed. J.K. Agee and D.R. Johnson, 41-61. Seattle, Washington, USA: University of Washington Press.

Brunelle, A., and C. Whitlock. 2003. Postglacial fire, vegetation, and climate history in the Clearwater Range, northern Idaho, USA. Quaternary Research 60: 307318 https://doi.org/10.1016/j.yqres.2003.07.009.

Cansler, C.A., and D. McKenzie. 2014. Climate, fire size, and biophysical setting control fire severity and spatial pattern in the northern Cascade Range, USA. Ecological Applications 24: 1037-1056 https://doi.org/10.1890/13-1077.1.

Carroll, A.L., S.W. Taylor, J. Régnière, and L. Safranyik. 2004. Effects of climate and climate change on the mountain pine beetle. In Challenges and solutions: proceedings of the mountain pine beetle symposium. Canadian Forest Service Information Report BC-X-39, ed. T.L. Shore, J.E. Brooks, and J.E. Stone, 221-230. Kelowna, British Columbia, Canada: Pacific Forestry Centre.

Case, M.J., B.K. Kerns, J.B. Kim, M. Day, A. Eglitis, M.L. Simpson, J. Beck, K. Grenier, and G. Riegel. 2019. Climate change effects on vegetation. In Climate change vulnerability and adaptation in south central Oregon. USDA Forest Service General Technical Report PNW-GTR-974, ed. J.E. Halofsky, D.L. Peterson, and J.J. Ho. Portland, Oregon, USA: USDA Forest Service, Pacific Northwest Research Station.

Chmura, D.J., P.D. Anderson, G.T. Howe, C.A. Harrington, J.E. Halofsky, D.L. Peterson, D.C. Shaw, and B.St. Clair. 2011. Forest responses to climate change in the northwestern United States: ecophysiological foundations for adaptive management. Forest Ecology and Management 261: 1121-1142 https://doi.org/ 10.1016/j.foreco.2010.12.040.

Clark, J.S., L. Iverson, C.W. Woodall, C.D. Allen, D.M. Bell, D.C. Bragg, A.W. D'Amato, F.W. Davis, M.H. Hersh, I. Ibanez, S.T. Jackson, S. Matthews, N. Pederson, M. Peters, M.W. Schwartz, K.M. Waring, and N.E. Zimmermann. 2016. The impacts of increasing drought on forest dynamics, structure, and biodiversity in the United States. Global Change Biology 22: 2329-2352 https://doi.org/ 10.1111/gcb.13160.

Crausbay, S.D., P.E. Higuera, D.G. Sprugel, and L.B. Brubaker. 2017. Fire catalyzed rapid ecological change in lowland coniferous forests of the Pacific Northwest over the past 14,000 years. Ecology. 98: 2356-2369 https://doi.org/ 10.1002/ecy.1897.

Creutzburg, M.K., R.M. Scheller, M.S. Lucash, S.D. LeDuc, and M.G. Johnson. 2017 Forest management scenarios in a changing climate: trade-offs between carbon, timber, and old forest. Ecological Applications 27: 503-518 https://doi. org/10.1002/eap.1460. 
Cwynar, L.C. 1987. Fire and the forest history of the North Cascade Range. Ecology. 68: 791-802 https://doi.org/10.2307/1938350.

Davis, C.M. 2018. Effects of climate change on cultural resources in the Northern Rockies region. Chapter 12. In Climate change vulnerability and adaptation in the Northern Rocky Mountains [Part 2]. USDA Forest Service General Technical Report RMRS-GTR-374, ed. J.E. Halofsky, D.L. Peterson, S.K. Dante-Wood, L. Hoang, J.J. Ho, and L.A. Joyce, 462-468. Fort Collins, Colorado, USA: USDA Forest Service, Rocky Mountain Research Station.

Davis, K.T., S.Z. Dobrowski, P.E. Higuera, Z.A. Holden, T.T. Veblen, M.T. Rother, S.A. Parks, A. Sala, and M.P. Maneta. 2019. Wildfires and climate change push low-elevation forests across a critical climate threshold for tree regeneration. Proceedings of the National Academy of Sciences, USA 116: 6193-6198 https:// doi.org/10.1073/pnas.1815107116.

Davis, R., Z. Yang, A. Yost, C. Belongie, and W. Cohen. 2017. The normal fire environment-modeling environmental suitability for large forest wildfires using past, present, and future climate normals. Forest Ecology and Management 390: 173-186 https://doi.org/10.1016/j.foreco.2017.01.027.

Dennison, P.E., S.C. Brewer, J.D. Arnold, and M.A. Moritz. 2014. Large wildfire trends in the western United States, 1984-2011. Geophysical Research Letters 41: 2928-2933 https://doi.org/10.1002/2014GL059576.

DeRose, R.J., and J.N. Long. 2009. Wildfire and spruce beetle outbreak: simulation of interacting disturbances in the central Rocky Mountains. Écoscience 16: 28-38 https://doi.org/10.2980/16-1-3160.

Dillon, G.K., Z.A. Holden, P. Morgan, M.A. Crimmins, E.K. Heyerdahl, and C.H. Luce. 2011. Both topography and climate affected forest and woodland burn severity in two regions of the western US, 1984 to 2006. Ecosphere. 2: 1-33 https://doi.org/10.1890/ES11-00271.1.

Dobrowski, S.Z., A.K. Swanson, J.T. Abatzoglou, Z.A. Holden, H.D. Safford, M.K. Schwartz, and D.G. Gavin. 2015. Forest structure and species traits mediate projected recruitment declines in western US tree species. Global Ecology and Biogeography 24: 917-927 https://doi.org/10.1111/geb.12302.

Dodson, E.K., and H.T. Root. 2013. Conifer regeneration following stand-replacing wildfire varies along an elevation gradient in a ponderosa pine forest, Oregon, USA. Forest Ecology and Management 302: 163-170 https://doi.org/ 10.1016/j.foreco.2013.03.050

Donato, D.C., J.B. Fontaine, J.L. Campbell, W.D. Robinson, J.B. Kauffman, and B.E. Law. 2009a. Conifer regeneration in stand-replacement portions of a large mixed-severity wildfire in the Klamath-Siskiyou Mountains. Canadian Journal of Forest Research 39: 823-838 https://doi.org/10.1139/X09-016.

Donato, D.C., J.B. Fontaine, J.B. Kauffman, W.D. Robinson, and B.E. Law. 2013. Fuel mass and forest structure following stand-replacement fire and post-fire logging in a mixed-evergreen forest. International Journal of Wildland Fire 22: 652-666 https://doi.org/10.1071/WF12109.

Donato, D.C., J.B. Fontaine, W.D. Robinson, J.B. Kauffman, and B.E. Law. 2009b. Vegetation response to a short interval between high-severity wildfires in a mixed-evergreen forest. Journal of Ecology 97: 142-154 https://doi.org/10. 1111/j.1365-2745.2008.01456.x.

Donato, D.C., B.J. Harvey, and M.G. Turner. 2016. Regeneration of montane forests 24 years after the 1988 Yellowstone fires: a fire-catalyzed shift in lower treelines? Ecosphere 7: e01410 https://doi.org/10.1002/ecs2.1410.

Downing, W.M., M.A. Krawchuk, G.W. Meigs, S.L. Haire, J.D. Coop, R.B. Walker, E. Whitman, G. Chong, and C. Miller. 2019. Influence of fire refugia spatial pattern on post-fire forest recovery in Oregon's Blue Mountains. Landscape Ecology 34: 771-792 https://doi.org/10.1007/s10980-019-00802-1.

Dugan, A.J., and W.L. Baker. 2015. Sequentially contingent fires, droughts and pluvials structured a historical dry forest landscape and suggest future contingencies. Journal of Vegetation Science 26: 697-710 https://doi.org/10. $1111 /$ jvs. 12266

Easterling, D.R., K.E. Kunkel, J.R. Arnold, T. Knutson, A.N. LeGrande, L.R. Leung, R.S. Vose, D.E. Waliser, and M.F. Wehner. 2017. Precipitation change in the United States. In Climate science special report: fourth national climate assessment, volume I, ed. D.J. Wuebbles, D.W. Fahey, K.A. Hibbard, D.J. Dokken, B.C. Stewart, and T.K. Maycock, 207-230. Washington, D.C.: US Global Change Research Program https://doi.org/10.7930/J0H993CC.

Edwards, M., M.A. Krawchuk, and P.J. Burton. 2015. Short-interval disturbance in lodgepole pine forests, British Columbia, Canada: understory and overstory response to mountain pine beetle and fire. Forest Ecology and Management 338: 163-175 https://doi.org/10.1016/j.foreco.2014.11.011.

EPA [Environmental Protection Agency]. 2014. Being prepared for climate change: a workbook for developing risk-based adaptation plans. EPA 842-K-14-002. Washington, D.C., USA: US Environmental Protection Agency, Office of Water.
Finney, D.L., R.M. Doherty, O. Wild, D.S. Stevenson, I.A. MacKenzie, and A.M. Blyth. 2018. A projected decrease in lightning under climate change. Nature Climate Change 8: 210-213 https://doi.org/10.1038/s41558-018-0072-6.

Flannigan, M.D., M.A. Krawchuk, W.J. de Groot, B.M. Wotton, and L.M. Gowman. 2009. Implications of changing climate for global wildland fire. International Journal of Wildland Fire 18: 483-507 https://doi.org/10.1071/WF08187.

Flower, A., D.G. Gavin, E.K. Heyerdahl, R.A. Parsons, and G.M. Cohn. 2014. Western spruce budworm outbreaks did not increase fire risk over the last three centuries: a dendrochronological analysis of inter-disturbance synergism. Plos One 9 (12): e114282 https://doi.org/10.1371/journal.pone.0114282.

Fontaine, J.B., D.C. Donato, W.D. Robinson, B.E. Law, and J.B. Kauffman. 2009. Bird communities following high-severity fire: response to single and repeat fires in a mixed-evergreen forest, Oregon, USA. Forest Ecology and Management 257: 1496-1504 https://doi.org/10.1016/j.foreco.2008.12.030.

Fried, J.S., J.K. Gilless, W.J. Riley, T.J. Moody, C.S. De Blas, K. Hayhoe, M. Moritz, S. Stephens, and M. Torn. 2008. Predicting the effect of climate change on wildfire behavior and initial attack success. Climatic Change. 87: 251-264 https://doi.org/10.1007/s10584-007-9360-2.

Furniss, M.J., N.J. Little, and D.L. Peterson. 2018. Effects of climate change on infrastructure. Chapter 11. In Climate change vulnerability and adaptation in the Intermountain Region [Part 2]. USDA Forest Service General Technical Report RMRS-GTR-375, ed. J.E. Halofsky, D.L. Peterson, J.J. Ho, N. Little, and L.A. Joyce, 339-362. Fort Collins, Colorado, USA: USDA Forest Service, Rocky Mountain Research Station.

Gavin, D.G., L.B. Brubaker, and D.N. Greenwald. 2013. Postglacial climate and fire-mediated vegetation change on the western Olympic Peninsula, Washington (USA). Ecological Monographs 83: 471-489 https://doi.org/10.1890/0012-9623-94.4.386.

Gavin, D.G., D.J. Hallett, F.S. Hu, K.P. Lertzman, S.J. Prichard, K.J. Brown, J.A. Lynch, P. Bartlein, and D.L. Peterson. 2007. Forest fire and climate change in western North America: insights from sediment charcoal records. Frontiers in Ecology and the Environment 5: 499-506 https://doi.org/10.1890/15409295(2007)5[499:FFACCI]2.0.CO;2.

Gedalof, Z.E., D.L. Peterson, and N.J. Mantua. 2005. Atmospheric, climatic, and ecological controls on extreme wildfire years in the northwestern United States. Ecological Applications 15: 154-174 https://doi.org/10.1890/035116.

Goheen, D.J., and E.M. Hansen. 1993. Effects of pathogens and bark beetles on forests. In Beetle-pathogen interactions in conifer forests, ed. T.D. Schowalter and G.M. Filip, 175-196. San Diego, California, USA: Academic Press.

Gray, A.N., and J.F. Franklin. 1997. Effects of multiple fires on the structure of southwestern Washington forests. Northwest Science 71: 174-185.

Halofsky, J.E., D.C. Donato, D.E. Hibbs, J.L. Campbell, M.D. Cannon, J.B. Fontaine, J.R. Thompson, R.G. Anthony, B.T. Bormann, L.J. Kayes, B.E. Law, D.L. Peterson, and T.A. Spies. 2011a. Mixed-severity fire regimes: lessons and hypotheses from the Klamath-Siskiyou Ecoregion. Ecosphere 2: 1-19 https://doi.org/10. 1890/ES10-00184.1.

Halofsky, J.E., M.A. Hemstrom, D.R. Conklin, J.S. Halofsky, B.K. Kerns, and D. Bachelet. 2013. Assessing potential climate change effects on vegetation using a linked model approach. Ecological Modelling 266: 131-143 https://doi. org/10.1016/j.ecolmodel.2013.07.003.

Halofsky, J.E., and D.L. Peterson, eds. 2017a. Climate change and Rocky Mountain ecosystems. Advances in global change research, volume 63. Cham, Switzerland: Springer International Publishing https://doi.org/10.1007/978-3319-56928-4

Halofsky, J.E., and D.L. Peterson. 2017b. Climate change vulnerability and adaptation in the Blue Mountains. USDA Forest Service General Technical Report PNW-GTR-939. Portland, Oregon, USA: USDA Forest Service, Pacific Northwest Research Station.

Halofsky, J.E., D.L. Peterson, and J.J. Ho. 2019. Climate change vulnerability and adaptation in south central Oregon. USDA Forest Service General Technical Report PNW-GTR-974. Portland, Oregon, USA: USDA Forest Service, Pacific Northwest Research Station.

Halofsky, J.E., D.L. Peterson, K.L. Metlen, M.G. Myer, and V.A. Sample. 2016. Developing and implementing climate change adaptation options in forest ecosystems: a case study in southwestern Oregon, USA. Forests 7: 268 https://doi.org/10.3390/f7110268.

Halofsky, J.E., D.L. Peterson, K.A. O'Halloran, and C. Hawkins Hoffman. 2011 b. Adapting to climate change at Olympic National Forest and Olympic National Park. USDA Forest Service General Technical Report PNW-GTR-844. Portland, Oregon, USA: USDA Forest Service, Pacific Northwest Research Station https://doi.org/10.2737/PNW-GTR-844. 
Halofsky, J.S., D.R. Conklin, D.C. Donato, J.E. Halofsky, and J.B. Kim. 2018a. Climate change, wildfire, and vegetation shifts in a high-inertia forest landscape. PLOS One 13: e0209490 https://doi.org/10.1371/journal.pone.0209490.

Halofsky, J.S., D.C. Donato, J.F. Franklin, J.E. Halofsky, D.L. Peterson, and B.J. Harvey. 2018b. The nature of the beast: examining climate adaptation options in forests with stand-replacing fire regimes. Ecosphere 9: e02140 https://doi.org/ 10.1002/ecs2.2140.

Halofsky, J.S., J.E. Halofsky, T. Burcsu, and M.A. Hemstrom. 2014. Dry forest resilience varies under simulated climate-management scenarios in a central Oregon, USA landscape. Ecological Applications 24: 1908-1925 https://doi. org/10.1890/13-1653.1.

Hand, M.S., D.L. Peterson, B.P. Blanchard, D.C. Benson, M.J. Crotteau, and L.K. Cerveny. 2019. Effects of climate change on recreation. In Climate change vulnerability and adaptation in south central Oregon. USDA Forest Service General Technical Report PNW-GTR-974, ed. J.E. Halofsky, D.L. Peterson, and J.J. Ho, 363-402. Portland, Oregon, USA: USDA Forest Service, Pacific Northwest Research Station.

Hansen, H.P. 1943. A pollen study of a subalpine bog in the Blue Mountains of northeastern Oregon. Ecology 24: 70-78 https://doi.org/10.2307/ 1929861.

Hart, S.J., T. Schoennagel, T.T. Veblen, and T.B. Chapman. 2015. Area burned in the western United States is unaffected by recent mountain pine beetle outbreaks. Proceedings of the National Academy of Sciences, USA 112: 43754380 https://doi.org/10.1073/pnas.1424037112.

Harvey, B.J., D.C. Donato, W.H. Romme, and M.G. Turner. 2013. Influence of recent bark beetle outbreak on fire severity and postfire tree regeneration in montane Douglas-fir forests. Ecology 94: 2475-2486 https://doi.org/10.1890/13-0188.1.

Harvey, B.J., D.C. Donato, W.H. Romme, and M.G. Turner. 2014a. Fire severity and tree regeneration following bark beetle outbreaks: the role of outbreak stage and burning conditions. Ecological Applications 24: 1608-1625 https://doi. org/10.1890/13-1851.1.

Harvey, B.J., D.C. Donato, and M.G. Turner. 2014b. Recent mountain pine beetle outbreaks, wildfire severity, and postfire tree regeneration in the US Northern Rockies. Proceedings of the National Academy of Sciences, USA 111: 1512015125 https://doi.org/10.1073/pnas.1411346111.

Harvey, B.J., D.C. Donato, and M.G. Turner. 2016a. Drivers and trends in landscape patterns of stand-replacing fire in forests of the US Northern Rocky Mountains (1984-2010). Landscape Ecology 31: 2367-2383 https://doi.org/10. 1007/s10980-016-0408-4.

Harvey, B.J., D.C. Donato, and M.G. Turner. 2016b. Burn me twice, shame on who? Interactions between successive forest fires across a temperate mountain region. Ecology 97: 2272-2282 https://doi.org/10.1002/ecy.1439.

Harvey, B.J., D.C. Donato, and M.G. Turner. 2016c. High and dry: post-fire tree seedling establishment in subalpine forests decreases with postfire drought and large stand-replacing burn patches. Global Ecology and Biogeography 25: 655-669 https://doi.org/10.1111/geb.12443.

Haugo, R.D., B.S. Kellogg, C.A. Cansler, C.A. Kolden, K.B. Kemp, J.C. Robertson, K.L. Metlen, N.M. Vaillant, and C.M. Restaino. 2019. The missing fire: quantifying human exclusion of wildfire in Pacific Northwest forests, USA. Ecosphere 10: e02702 https://doi.org/10.1002/ecs2.2702.

Hellmann, J.J., J.E. Byers, B.J. Bierwagen, and J.S. Dukes. 2008. Five potential consequences of climate change for invasive species. Conservation Biology 22: 534-543 https://doi.org/10.1111/j.1523-1739.2008.00951.x.

Hessburg, P.F., J.K. Agee, and J.F. Franklin. 2005. Dry forests and wildland fires of the inland northwest USA: contrasting the landscape ecology of the presettlement and modern eras. Forest Ecology and Management 211: 117-139 https://doi.org/10.1016/j.foreco.2005.02.016.

Hessburg, P.F., D.J. Churchill, A.J. Larson, R.D. Haugo, C. Miller, T.A. Spies, M.P. North, N.A. Povak, R.T. Belote, P.H. Singleton, W.L. Gaines, R.E. Keane, and G.H. Aplet. 2015. Restoring fire-prone inland Pacific landscapes: seven core principles. Landscape Ecology 30: 1805-1835 https://doi.org/10.1007/s10980-015-0218-0.

Hessl, A.E., D. McKenzie, and R. Schellhaas. 2004. Drought and Pacific Decadal Oscillation linked to fire occurrence in the inland Pacific Northwest. Ecological Applications 14: 425-444 https://doi.org/10.1890/03-5019.

Heyerdahl, E.K., L.B. Brubaker, and J.K. Agee. 2002. Annual and decadal climate forcing of historical fire regimes in the interior Pacific Northwest. The Holocene 12: 597-604 https://doi.org/10.1191/0959683602hl570rp.

Heyerdahl, E.K., D. McKenzie, L. Daniels, A.E. Hessl, J.S. Littell, and N.J. Mantua. 2008. Climate drivers of regionally synchronous fires in the inland Northwest (1651-1900). International Journal of Wildland Fire 17: 40-49 https://doi.org/ 10.1071/WF07024.
Hicke, J.A., M.C. Johnson, J.L. Hayes, and H.K. Preisler. 2012. Effects of bark beetlecaused tree mortality on wildfire. Forest Ecology and Management 271: 81-90 https://doi.org/10.1016/j.foreco.2012.02.005.

Hicke, J.A., J.S. Logan, J.A. Powell, and D.S. Ojima. 2006. Changes in temperature influence suitability for modeled mountain pine beetle (Dendroctonus ponderosae) outbreaks in the western United States. Journal of Geophysical Research 111: G02019 https://doi.org/10.1029/2005JG000101.

Hidalgo, H.G., T. Das, M.D. Dettinger, D.R. Cayan, D.W. Pierce, T.P. Barnett, G. Bala, A. Mirin, A.W. Wood, C. Bonfils, B.D. Santer, and T. Nozawa. 2009. Detection and attribution of streamflow timing changes to climate change in the western United States. Journal of Climate 22: 3838-3855 https://doi.org/10. 1175/2009JCLI2470.1

Hoffman, C.M., P. Morgan, W. Mell, R. Parsons, E.K. Strand, and S. Cook. 2012. Numerical simulation of crown fire hazard immediately after bark beetlecaused mortality in lodgepole pine forests. Forest Science 58: 178-188 https:// doi.org/10.5849/forsci.10-137.

Hoffman, C.M., P. Morgan, W. Mell, R. Parsons, E.K. Strand, and S. Cook. 2013. Surface fire intensity influences simulated crown fire behavior in lodgepole pine forests with recent mountain pine beetle-caused tree mortality. Forest Science 59: 390-399 https://doi.org/10.5849/forsci.11-114.

Holden, Z.A., A. Swanson, C.H. Luce, W.M. Jolly, M. Maneta, J.W. Oyler, D.A. Warren, R. Parsons, and D. Affleck. 2018. Decreasing fire season precipitation increased recent western US forest wildfire activity. Proceedings of the National Academy of Sciences, USA 115 (36): E8349-E8357 https://doi. org/10.1073/pnas.1802316115.

Hudec, J.L., J.E. Halofsky, D.L. Peterson, and J.J. Ho. 2019. Climate change vulnerability and adaptation in southwest Washington. USDA Forest Service General Technical Report PNW-GTR-977. Portland, Oregon, USA: USDA Forest Service, Pacific Northwest Research Station.

Isaac, L.A. 1940. Vegetation succession following logging in the Douglas-fir region with special reference to fire. Journal of Forestry 38: 716-721.

Isaac, L.A., and G.S. Meagher. 1936. Natural reproduction on the Tillamook burn two years after the fire. Portland, Oregon, USA: US Department of Agriculture, Forest Senvice.

Isaak, D.J., C.H. Luce, B.E. Rieman, D.E. Nagel, E.E. Peterson, D.L. Horan, S. Parkes, and G.L. Chandler. 2010. Effects of climate change and wildfire on stream temperatures and salmonid thermal habitat in a mountain river network. Ecological Applications 20: 1350-1371 https://doi.org/10.1890/09-0822.1.

Itter, M.S., A.O. Finley, M.B. Hooten, P.E. Higuera, J.R. Marlon, R. Kelly, and J.S. McLachlan. 2017. A model-based approach to wildland fire reconstruction using sediment charcoal records. Environmetrics 28: e2450 https://doi.org/10.1002/env.2450.

Jenkins, M.J., J.B. Runyon, C.J. Fettig, W.G. Page, and B.J. Bentz. 2014. Interactions among the mountain pine beetle, fires, and fuels. Forest Science 60: 489-501 https://doi.org/10.5849/forsci.13-017.

Jiang, X., S.A. Rauscher, T.D. Ringler, D.M. Lawrence, A.P. Williams, C.D. Allen, A.L. Steiner, D.M. Cai, and N.G. McDowell. 2013. Projected future changes in vegetation in western North America in the twenty-first century. Journal of Climate 26: 3671-3687 https://doi.org/10.1175/JCLI-D-12-00430.1.

Johnstone, J.F., F.S. Chapin, T.N. Hollingsworth, M.C. Mack, V. Romanovsky, and M. Turetsky. 2010. Fire, climate change, and forest resilience in interior Alaska. Canadian Journal of Forest Research 40: 1302-1312 https://doi.org/10.1139/ X10-061.

Jolly, W.M., R.A. Parsons, A.M. Hadlow, G.M. Cohn, S.S. McAllister, J.B. Popp, R.M. Hubbard, and J.F. Negrón. 2012. Relationships between moisture, chemistry, and ignition of Pinus contorta needles during the early stages of mountain pine beetle attack. Forest Ecology and Management 269: 52-59 https://doi.org/10.1016/j.foreco.2011.12.022.

Joyce, L.A., G.M. Blate, S.G. McNulty, C.I. Millar, S. Moser, R.P. Neilson, and D.L. Peterson. 2009. Managing for multiple resources under climate change: national forests. Environmental Management 44: 1022-1032 https://doi.org/ 10.1007/s00267-009-9324-6.

Keane, R.E., P. Morgan, and S.W. Running. 1996. Fire-BGC - a mechanistic ecological process model for simulating fire succession on coniferous forest landscapes of the Northern Rocky Mountains. USDA Forest Service Research Paper INT-484. Ogden, Utah, USA: USDA Forest Service, Intermountain Research Station.

Keane, R.E., P. Morgan, and J.D. White. 1999. Temporal patterns of ecosystem processes on simulated landscapes in Glacier National Park, Montana, USA. Landscape Ecology 14: 311-329 https://doi.org/10.1023/A:1008011916649.

Keeley, J.E., G. Ne'eman, and C.J. Fotheringham. 1999. Immaturity risk in a firedependent pine. Journal of Mediterranean Ecology 1: 41-48. 
Keeley, J.E., and A.D. Syphard. 2016. Climate change and future fire regimes: examples from California. Geosciences 6: 37 https://doi.org/10.3390/ geosciences6030037.

Kerns, B.K., D.C. Powell, S. Mellmann-Brown, G. Carnwath, and J.B. Kim. 2017. Effects of climatic variability and change on upland vegetation in the Blue Mountains. In Climate change vulnerability and adaptation in the Blue Mountains. USDA Forest Service General Technical Report PNW-GTR939, ed. J.E. Halofsky and D.L. Peterson, 149-250. Portland, Oregon, USA USDA Forest Service, Pacific Northwest Research Station.

Kitzberger, T., D.A. Falk, A.L. Westerling, and T.W. Swetnam. 2017. Direct and indirect climate controls predict heterogeneous early-mid 21st century wildfire burned area across western and boreal North America. PloS One 12: e0188486 https://doi.org/10.1371/journal.pone.0188486.

Klopfenstein, N.B., M.-S. Kim, J.W. Hanna, B.A. Richardson, and J.E. Lundquist. 2009. Approaches to predicting potential impacts of climate change on forest disease: an example with Armillaria root disease. USDA Forest Service Research Paper RMRS-RP-76. Fort Collins, Colorado, USA: USDA Forest Service, Rocky Mountain Research Station https://doi.org/10.2737/RMRSRP-76.

Klutsch, J.G., M.A. Battaglia, D.R. West, S.L. Costello, and J.F. Negrón. 2011. Evaluating potential fire behavior in lodgepole pine-dominated forests after a mountain pine beetle epidemic in north-central Colorado. Western Journal of Applied Forestry 26: 101-109 https://doi.org/10.1093/wjaf/26.3.101.

Krawchuk, M.A., M.A. Moritz, M. Parisien, J. Van Dorn, and K. Hayhoe. 2009. Global pyrogeography: the current and future distribution of wildfire. PLoS One 4: e5102 https://doi.org/10.1371/journal.pone.0005102.

Kulakowski, D., and D. Jarvis. 2011. The influence of mountain pine beetle outbreaks and drought on severe wildfires in northwestern Colorado and southern Wyoming: a look at the past century. Forest Ecology and Management 262: 1686-1696 https://doi.org/10.1016/j.foreco.2011.07.016.

Larson, A.J., R.T. Belote, C.A. Cansler, S.A. Parks, and M.S. Dietz. 2013. Latent resilience in ponderosa pine forest: effects of resumed frequent fire. Ecological Applications 23: 1243-1249 https://doi.org/10.1890/13-0066.1.

Littell, J.S., D. McKenzie, D.L. Peterson, and A.L. Westerling. 2009. Climate and wildfire area burned in western US ecoprovinces, 1916-2003. Ecological Applications 19: 1003-1021 https://doi.org/10.1890/07-1183.1.

Littell, J.S., D. McKenzie, H.Y. Wan, and S.A. Cushman. 2018. Climate change and future wildfire in the western United States: an ecological approach to nonstationarity. Earth's Future 6: 1097-1111 https://doi.org/10.1029/ 2018EF000878

Littell, J.S., E.E. Oneil, D. McKenzie, J.A. Hicke, J.A. Lutz, R.A. Norheim, and M.M. Elsner. 2010. Forest ecosystems, disturbance, and climatic change in Washington state, USA. Climatic Change 102: 129-158 https://doi.org/10. 1007/s10584-010-9858-X

Littell, J.S., D.L. Peterson, K.L. Riley, Y. Liu, and C.H. Luce. 2016. A review of the relationships between drought and forest fire in the United States. Global Change Biology 22: 2353-2369 https://doi.org/10.1111/gcb.13275.

Littell, J.S., D.L. Peterson, and M. Tjoelker. 2008. Douglas-fir growth in mountain ecosystems: water limits tree growth from stand to region. Ecological Monographs 78: 349-368 https://doi.org/10.1890/07-0712.1.

Little, R.L., D.L. Peterson, and L.L. Conquest. 1994. Regeneration of subalpine fir (Abies lasiocarpa) following fire: effects of climate and other factors. Canadian Journal of Forest Research 24: 934-944 https://doi.org/10.1139/x94-123.

Littlefield, C.E. 2019. Topography and post-fire climatic conditions shape spatiotemporal patterns of conifer establishment and growth. Fire Ecology 15: 34 https://doi.org/10.1186/s42408-019-0047-7.

Loehman, R.A., R.E. Keane, L.M. Holsinger, and Z. Wu. 2017. Interactions of landscape disturbances and climate change dictate ecological pattern and process: spatial modeling of wildfire, insect, and disease dynamics under future climates. Landscape Ecology 32: 1447-1459 https://doi.org/10.1007/ s10980-016-0414-6.

Logan, J.A., and B.J. Bentz. 1999. Model analysis of mountain pine beetle (Coleoptera: Scolytidae) seasonality. Environmental Entomology 28: 924-934 https://doi.org/10.1093/ee/28.6.924

Logan, J.A., and J.A. Powell. 2009. Ecological consequences of forest-insect disturbance altered by climate change. In Climate warming in western North America, ed. F.H. Wagner, 98-109. Salt Lake City, Utah, USA: University of Utah Press.

Long, C.J., C. Whitlock, P.J. Bartlein, and S.H. Millspaugh. 1998. A 9000-year fire history from the Oregon Coast Range, based on a high-resolution charcoal study. Canadian Journal of Forest Research 28: 774-787 https://doi.org/10. 1139/cjfr-28-5-774.
Luce, C., P. Morgan, K. Dwire, D. Isaak, Z. Holden, and B. Rieman. 2012. Climate change, forests, fire, water, and fish: building resilient landscapes, streams, and managers. USDA Forest Service General Technical Report RMRS-GTR-290. Fort Collins, Colorado, USA: USDA Forest Service, Rocky Mountain Research Station https://doi.org/10.2737/RMRS-GTR-290.

Luce, C.H., J.T. Abatzoglou, and Z.A. Holden. 2013. The missing mountain water: slower westerlies decrease orographic enhancement in the Pacific Northwest USA. Science 342: 1360-1364 https://doi.org/10.1126/science.1242335.

Luce, C.H., and Z.A. Holden. 2009. Declining annual streamflow distributions in the Pacific Northwest United States, 1948-2006. Geophysical Research Letters 36: L16401 https://doi.org/10.1029/2009GL039407.

Lupo, A.R., R.J. Oglesby, and I.I. Mokhov. 1997. Climatological features of blocking anticyclones: a study of northern hemisphere CCM1 model blocking events in present-day and double $\mathrm{CO}_{2}$ concentration atmosphere. Climate Dynamics 13: 181-195 https://doi.org/10.1007/s003820050159.

Lyons-Tinsley, C.M., and D.L. Peterson. 2012. Surface fuel treatments in young, regenerating stands affect wildfire severity in a mixed conifer forest, eastside Cascade Range, Washington, USA. Forest Ecology and Management 270: $117-$ 125 https://doi.org/10.1016/j.foreco.2011.04.016.

Manion, P.D. 1991. Tree disease concepts. 2nd ed. Englewood Cliffs, New Jersey, USA: Prentice Hall.

Mantua, N., I. Tohver, and A. Hamlet. 2010. Climate change impacts on streamflow extremes and summertime stream temperature and their possible consequences for freshwater salmon habitat in Washington State. Climatic Change 102: 187-223 https://doi.org/10.1007/s10584-0109845-2.

Mantua, N.J., S.R. Hare, Y. Zhang, J.M. Wallace, and R.C. Francis. 1997. A Pacific interdecadal climate oscillation with impacts on salmon production. Bulletin of the American Meteorological Society 78: 1069-1079 https://doi.org/10.1175/ 1520-0477(1997)078\%3C1069:APICOW\%3E2.0.CO;2.

Marlier, M.E., M. Xiao, R. Engel, B. Livneh, J.T. Abatzoglou, and D.P. Lettenmaier. 2017. The 2015 drought in Washington state: a harbinger of things to come? Environmental Research Letters 12: 114008 https:/doi.org/10.1088/1748-9326/aa8fde.

Martinson, E.J., and P.N. Omi. 2013. Fuel treatments and fire severity: a metaanalysis. USDA Forest Service Research Paper RMRS-RP-103WWW. Fort Collins, Colorado, USA: USDA Forest Service, Rocky Mountain Research Station https://doi.org/10.2737/RMRS-RP-103.

McKenzie, D., Z. Gedalof, D.L. Peterson, and P. Mote. 2004. Climatic change, wildfire, and conservation. Conservation Biology 18: 890-902 https://doi.org/ 10.1111/j.1523-1739.2004.00492.x.

McKenzie, D., and J.S. Littell. 2017. Climate change and the eco-hydrology of fire: will area burned increase in a warming western USA? Ecological Applications 27: 26-36 https://doi.org/10.1002/eap.1420.

McKenzie, D., D.L. Peterson, and J.S. Littell. 2009. Global warming and stress complexes in forests of western North America. In Wildland fires and air pollution, ed. A. Bytnerowicz, M.J. Arbaugh, A.R. Riebau, and C. Andersen, 317-337. The Hague, The Netherlands: Elsevier Publishers https://doi.org/10. 1016/S1474-8177(08)00015-6.

Meddens, A.J., C.A. Kolden, J.A. Lutz, J.T. Abatzoglou, and A.T. Hudak. 2018. Spatiotemporal patterns of unburned areas within fire perimeters in the northwestern United States from 1984 to 2014. Ecosphere 9: e02029 https:// doi.org/10.1002/ecs2.2029.

Meigs, G.W., J.L. Campbell, H.S.J. Zald, J.D. Bailey, D.C. Shaw, and R.E. Kennedy. 2015. Does wildfire likelihood increase following insect outbreaks in conifer forests? Ecosphere 6: 118 https://doi.org/10.1890/ES15-00037.1.

Meigs, G.W., H.S.J. Zald, J.L. Campbell, W.S. Keeton, and R.E. Kennedy. 2016. Do insect outbreaks reduce the severity of subsequent forest fires? Environmental Research Letters 11: 045008 https://doi.org/10.1088/1748-9326/ $11 / 4 / 045008$

Melvin, M.A. 2018. 2018 national prescribed fire use survey report. Technical Report 03-18. National Association of State Foresters and the Coalition of Prescribed Fire Councils. https://www.stateforesters.org/wp-content/ uploads/2018/12/2018-Prescribed-Fire-Use-Survey-Report-1.pdf Accessed 6 Nov 2019.

Millar, C.I., C.W. Swanston, and D.L. Peterson. 2014. Adapting to climate change. In Climate change and United States forests, ed. D.L. Peterson, J.M. Vose, and T. Patel-Weynand, 183-222. Dordrecht, The Netherlands: Springer https://doi. org/10.1007/978-94-007-7515-2_8.

Milne, B.T., V.K. Gupta, and C. Restrepo. 2002. A scale-invariant coupling of plants, water, energy, and terrain. Écoscience 9: 191-199 https://doi.org/10.1080/ 11956860.2002 .11682705 
Minore, D., and R.J. Laacke. 1992. Natural regeneration. In Reforestation practices in southwestern Oregon and northern California, ed. S.D. Hobbs, S.D. Tesch, P.W. Owston, R.E. Stewart, J.C. Tappeiner, and G.E. Wells, 258-283. Corvallis, Oregon, USA: Oregon State University Press.

Moritz, M.A., M.A. Parisien, E. Batllori, M.A. Krawchuk, J. Van Dorn, D.J. Ganz, and K. Hayhoe. 2012. Climate change and disruptions to global fire activity. Ecosphere 3: 1-22 https://doi.org/10.1890/ES11-00345.1.

Mote, P.W., J.T. Abatzoglou, and K.E. Kunkel. 2014. Climate variability and change in the past and the future. In Climate change in the Northwest: implications for our landscapes, waters, and communities, ed. M.M. Dalton, P.W. Mote, and A. Snover, 25-40. Washington, D.C., USA: Island Press.

Mote, P.W., S. Li, D.P. Lettenmaier, M. Xiao, and R. Engel. 2018. Dramatic declines in snowpack in the western US. Climate and Atmospheric Science 1: 2 https:// doi.org/10.1038/s41612-018-0012-1.

Nelson, K.N., M.G. Turner, W.H. Romme, and D.B. Tinker. 2016. Landscape variation in tree regeneration and snag fall drive fuel loads in 24-year old post-fire lodgepole pine forests. Ecological Applications 26: 2424-2438 https://doi.org/ 10.1002/eap.1412

Nelson, K.N., M.G. Turner, W.H. Romme, and D.B. Tinker. 2017. Simulated fire behaviour in young, postfire lodgepole pine forests. International Journal of Wildland Fire 26: 852-865 https://doi.org/10.1071/WF16226.

Nitschke, C.R., M. Amoroso, K.D. Coates, and R. Astrup. 2012. The influence of climate change, site type, and disturbance on stand dynamics in northwest British Columbia, Canada. Ecosphere 3 (1): 11 https://doi.org/10.1890/ES11-00282.1.

North, M.P., J.T. Stevens, D.F. Greene, M. Coppoletta, E.E. Knapp, A.M. Latimer, C.M. Restaino, R.E. Tompkins, K.R. Welch, R.A. York, D.J. Young, J.N. Axelson, T.N. Buckley, B.L. Estes, R.N. Hager, J.W. Long, M.D. Meyer, S.M. Ostoja, H.D. Safford, K.L. Shive, C.L. Tubbesing, H. Vice, D. Walsh, C.M. Werner, and P. Wyrsch. 2019. Tamm review: reforestation for resilience in dry western US forests. Forest Ecology and Management 432: 209-224 https://doi.org/10.1016/j.foreco.2018.09.007.

Page, W., and M. Jenkins. 2007. Mountain pine beetle-induced changes to selected lodgepole pine fuel complexes within the Intermountain Region. Forest Science 53: 507-518.

Paine, R.T., M.J. Tegner, and E.A. Johnson. 1998. Compounded perturbations yield ecological surprises. Ecosystems 1: 535-545 https://doi.org/10.1007/ s100219900049.

Parker, T.J., K.M. Clancy, and R.L. Mathiasen. 2006. Interactions among fire, insects and pathogens in coniferous forests of the interior western United States and Canada. Agricultural and Forest Entomology 8: 167-189 https://doi.org/10 1111/j.1461-9563.2006.00305.x.

Parks, S.A., L.M. Holsinger, C. Miller, and C.R. Nelson. 2015. Wildland fire as a selfregulating mechanism: the role of previous burns and weather in limiting fire progression. Ecological Applications 25: 1478-1492 https://doi.org/10. 1890/14-1430.1.

Parks, S.A., C. Miller, J.T. Abatzoglou, L.M. Holsinger, M.A. Parisien, and S.Z. Dobrowski. 2016a. How will climate change affect wildland fire severity in the western US? Environmental Research Letters 11: 035002 https://doi.org/10.1088/1748-9326/11/ 3/035002.

Parks, S.A., C. Miller, L.M. Holsinger, L.S. Baggett, and B.J. Bird. 2016b. Wildland fire limits subsequent fire occurrence. International Journal of Wildland Fire 25: 182-190 https://doi.org/10.1071/WF15107.

Parks, S.A., C. Miller, C.R. Nelson, and Z.A. Holden. 2014. Previous fires moderate burn severity of subsequent wildland fires in two large western US wilderness areas. Ecosystems 17: 29-42 https://doi.org/10. 1007/s10021-013-9704-x.

Perrakis, D.D.B., R.A. Lanoville, S.W. Taylor, and D. Hicks. 2014. Modeling wildfire spread in mountain pine beetle-affected forest stands, British Columbia Canada. Fire Ecology 10: 10-35 https://doi.org/10.4996/fireecology.1002010.

Peterson, D.L., J.E. Halofsky, and M.C. Johnson. 2011a. Managing and adapting to changing fire regimes in a warmer climate. In The landscape ecology of fire, ed. D. McKenzie, C. Miller, and D. Falk, 249267. New York, New York, USA: Springer https://doi.org/10.1007/978-94007-0301-8_10.

Peterson, D.L., M.C. Johnson, J.K. Agee, T.B. Jain, D. McKenzie, and E.D. Reinhardt. 2005. Forest structure and fire hazard in dry forests of the western United States. USDA Forest Service General Technical Report PNW-GTR-628. Portland, Oregon, USA: USDA Forest Service, Pacific Northwest Research Station https://doi.org/ 10.2737/PNW-GTR-628.

Peterson, D.L., C.I. Millar, L.A. Joyce, M.J. Furniss, J.E. Halofsky, R.P. Neilson, and T.L. Morelli. 2011 b. Responding to climate change on national forests: a guidebook for developing adaptation options. USDA Forest Service General Technical Report PNW-GTR-855. Portland, Oregon, USA: USDA Forest Service, Pacific Northwest Research Station https://doi.org/10.2737/PNW-GTR-855.

Petrie, M., A. Wildeman, J. Bradford, R. Hubbard, and W. Lauenroth. 2016. A review of precipitation and temperature control on seedling emergence and establishment for ponderosa and lodgepole pine forest regeneration. Forest Ecology and Management 361: 328-338 https://doi.org/10.1016/j.foreco.2015. 11.028 .

Petrie, M.D., J.B. Bradford, R.M. Hubbard, W.K. Lauenroth, C.M. Andrews, and D.R. Schlaepfer 2017. Climate change may restrict dryland forest regeneration in the 21 st century. Ecology 98: 1548-1559 https://doi.org/10.1002/ecy.1791.

Price, C., and D. Rind. 1994. Possible implications of global climate change on global lightning distributions and frequencies. Journal of Geophysical Research 99: 10823-10831 https://doi.org/10.1029/94JD00019.

Prichard, S.J., Z. Gedalof, W.W. Oswald, and D.L. Peterson. 2009. Holocene fire and vegetation dynamics in a montane forest, North Cascade Range, Washington, USA. Quaternary Research 72: 57-67 https://doi.org/10.1016/j. yqres.2009.03.008.

Prichard, S.J., and M.C. Kennedy. 2014. Fuel treatments and landform modify landscape patterns of burn severity in an extreme fire event. Ecological Applications 24: 571-590 https://doi.org/10.1890/13-0343.1.

Prichard, S.J., C.S. Stevens-Rumann, and P.F. Hessburg. 2017. Tamm review: shifting global fire regimes: lessons from reburns and research needs. Forest Ecology and Management 396: 217-233 https://doi.org/10.1016/j.foreco.2017. 03.035

Raymond, C.L., D.L. Peterson, and R.M. Rochefort. 2014. Climate change vulnerability and adaptation in the North Cascades region, Washington. USDA Forest Service General Technical Report PNW-GTR-892. Portland, Oregon, USA: USDA Forest Service, Pacific Northwest Research Station https://doi.org/10. 2737/PNW-GTR-892.

Reeve, N., and R. Toumi. 1999. Lightning activity as an indicator of climate change. Quarterly Journal of the Royal Meteorological Society 125: 893-903 https://doi.org/10.1002/qj.49712555507.

Reilly, M.J., C.J. Dunn, G.W. Meigs, T.A. Spies, R.E. Kennedy, J.D. Bailey, and K. Briggs. 2017. Contemporary patterns of fire extent and severity in forests of the Pacific Northwest, USA (1985-2010). Ecosphere 8: e01695 https://doi.org/10.1002/ecs2. 1695.

Reilly, M.J., M. Elia, T.A. Spies, M.J. Gregory, G. Sanesi, and R. Lafortezza. 2018. Cumulative effects of wildfires on forest dynamics in the eastern Cascade Mountains, USA. Ecological Applications 28: 291-308 https://doi.org/10.1002/ eap.1644.

Restaino, C.M., D.L. Peterson, and J.S. Littell. 2016. Increased water deficit decreases Douglas-fir growth throughout western US forests. Proceedings of the National Academy of Sciences, USA 113: 9557-9562 https://doi.org/10. 1073/pnas.1602384113.

Roberts, S.D., and C.A. Harrington. 2008. Individual tree growth response to variable-density thinning in coastal Pacific Northwest forests. Forest Ecology and Management 255: 2771-2781 https://doi.org/10.1016/j.foreco.2008. 01.043.

Rogers, B.M., R.P. Neilson, R. Drapek, J.M. Lenihan, J.R. Wells, D. Bachelet, and B.E. Law. 2011. Impacts of climate change on fire regimes and carbon stocks of the US Pacific Northwest. Journal of Geophysical Research-Biogeosciences 116: G03037 https://doi.org/10.1029/2011JG001695.

Romps, D.M., J.T. Seeley, D. Vollaro, and J. Molinari. 2014. Projected increase in lightning strikes in the United States due to global warming. Science 346: 851-854 https://doi.org/10.1126/science.1259100.

Rother, M.T., and T.T. Veblen. 2017. Climate drives episodic conifer establishment after fire in dry ponderosa pine forests of the Colorado Front Range, USA. Forests 8: 159 https://doi.org/10.3390/f8050159.

Rother, M.T., T.T. Veblen, and L.G. Furman. 2015. A field experiment informs expected patterns of conifer regeneration after disturbance under changing climate conditions. Canadian Journal of Forest Research 45: 1607-1616 https://doi.org/10.1139/cjfr-2015-0033.

Rowe, J.S. 1983. Concepts of fire effects on plant individuals and species. In The role of fire in northern circumpolar ecosystems, ed. R.W. Wein and D.A. Maclean, 135-154. New York, New York, USA: Wiley.

Safeeq, M., G.E. Grant, S.L. Lewis, and C.L. Tague. 2013. Coupling snowpack and groundwater dynamics to interpret historical streamflow trends in the western United States. Hydrological Processes 27: 655-668 https://doi.org/10. 1002/hyp.9628.

Safford, H.D., J.T. Stevens, K. Merriam, M.D. Meyer, and A.M. Latimer. 2012. Fuel treatment effectiveness in California yellow pine and mixed conifer forests. 
Forest Ecology and Management 274: 17-28 https://doi.org/10.1016/j.foreco. 2012.02.013.

Savage, M., J.N. Mast, and J.J. Feddema. 2013. Double whammy: high-severity fire and drought in ponderosa pine forests of the Southwest. Canadian Journal of Forest Research 43: 570-583 https://doi.org/10.1139/cjfr-2012-0404.

Scheller, R.M., and D.J. Mladenoff. 2008. Simulated effects of climate change, tree species migration, and forest fragmentation on aboveground carbon storage on a forested landscape. Climate Research 36: 191-202 https://doi.org/10. 3354/cr00745.

Schwantes, A.M., J.J. Swenson, and R.B. Jackson. 2016. Quantifying drought-induced tree mortality in the open canopy woodlands of central Texas. Remote Sensing of Environment 181: 54-64 https://doi.org/10.1016/.rse.2016.03.027.

Sea, D.S., and C. Whitlock. 1995. Postglacial vegetation and climate of the Cascade Range, central Oregon. Quaternary Research 43: 370-381 https://doi. org/10.1006/qres.1995.1043.

Shatford, J.P.A., D.E. Hibbs, and K.J. Puettmann. 2007. Conifer regeneration after forest fire in the Klamath-Siskiyous: how much, how soon? Journal of Forestry 105: 139-146

Sheehan, T., D. Bachelet, and K. Ferschweiler. 2015. Projected major fire and vegetation changes in the Pacific Northwest of the conterminous United States under selected CMIP5 climate futures. Ecological Modelling 317: 16-29 https://doi.org/10.1016/j.ecolmodel.2015.08.023.

Shive, K.L., C.H. Sieg, and P.Z. Fulé. 2013. Pre-wildfire management treatments interact with fire severity to have lasting effects on post-wildfire vegetation response. Forest Ecology and Management 297: 75-83 https://doi.org/10. 1016/j.foreco.2013.02.021.

Simard, M., W.H. Romme, J.M. Griffin, and M.G. Turner. 2011. Do mountain pine beetle outbreaks change the probability of active crown fire in lodgepole pine forests? Ecological Monographs 81: 3-24 https://doi.org/10.1890/10-1176.1.

Singleton, P.H., M. Case, K. Keown, A. Markus, K. Mellen-McLean, S. Mohren, and L. Turner. 2019. Climate change, wild life, and wildlife habitats in south central Oregon. In Climate change vulnerability and adaptation in south central Oregon. USDA Forest Service General Technical Report PNW-GTR-974, ed. J.E. Halofsky, D.L. Peterson, and J.J. Ho, 297-362. Portland, Oregon, USA: USDA Forest Service, Pacific Northwest Research Station.

Sohn, J.A., S. Saha, and J. Bauhus. 2016. Potential of forest thinning to mitigate drought stress: a meta-analysis. Forest Ecology and Management 380: 261-273 https://doi.org/10.1016/j.foreco.2016.07.046.

Spies, T.A., T.W. Giesen, F.J. Swanson, J.F. Franklin, D. Lach, and K.N. Johnson. 2010. Climate change adaptation strategies for federal forests of the Pacific Northwest, USA: ecological, policy, and socio-economic perspectives. Landscape Ecology 25: 1185-1199 https://doi.org/10.1007/ s10980-010-9483-0.

Stavros, E.N., J. Abatzoglou, N.K. Larkin, D. McKenzie, and E.A. Steel. 2014. Climate and very large wildland fires in the contiguous western USA. International Journal of Wildland Fire 23: 899-914 https://doi.org/10.1071/WF13169.

Stein, B.A., A. Staudt, M.S. Cross, N.S. Dubois, C. Enquist, R. Griffis, L.J. Hansen, J.J. Hellmann, J.J. Lawler, E.J. Nelson, and A. Pairis. 2013. Preparing for and managing change: climate adaptation for biodiversity and ecosystems. Frontiers in Ecology and the Environment 11: 502-510 https:// doi.org/10.1890/120277.

Stephens, S.L., J.K. Agee, P.Z. Fulé, M.P. North, W.H. Romme, T.W. Swetnam, and M.G. Turner. 2013. Managing forests and fire in changing climates. Science 342: 41-42 https://doi.org/10.1126/science.1240294.

Stephens, S.L., B.M. Collins, C.J. Fettig, M.A. Finney, C.M. Hoffman, E.E. Knapp, M.P. North, H. Safford, and R.B. Wayman. 2018. Drought, tree mortality, and wildfire in forests adapted to frequent fire. Bioscience 68: 77-88 https://doi. org/10.1093/biosci/bix146.

Stephenson, N.L. 1998. Actual evapotranspiration and deficit: biologically meaningful correlates of vegetation distribution across spatial scales. Journal of Biogeography 25: 855-870 https://doi.org/10.1046/j.1365-2699.1998.00233.x.

Stevens-Rumann, C., and P. Morgan. 2016. Repeated wildfires alter forest recovery of mixed-conifer ecosystems. Ecological Applications 26: 1842-1853 https:// doi.org/10.1890/15-1521.1.

Stevens-Rumann, C., P. Morgan, and C. Hoffman. 2015. Bark beetles and wildfires: how does forest recovery change with repeated disturbances in mixed conifer forests? Ecosphere 6 (6): 100 https://doi.org/10.1890/ES14-00443.1.

Stevens-Rumann, C.S., K.B. Kemp, P.E. Higuera, B.J. Harvey, M.T. Rother, D.C. Donato, P. Morgan, and T.T. Veblen. 2017. Evidence for declining forest resilience to wildfires under climate change. Ecology Letters 21: 243-252 https://doi.org/10.1111/ele.12889.
Stevens-Rumann, C.S., S.J. Prichard, E.K. Strand, and P. Morgan. 2016. Prior wildfires influence burn severity of subsequent large fires. Canadian Journal of Forest Research 46: 1375-1385 https://doi.org/10.1139/cjfr-2016-0185.

Sturrock, R.N., S.J. Frankel, A.V. Brown, P.E. Hennon, J.T. Kliejunas, K.J. Lewis, J.J. Worrall, and A.J. Woods. 2011. Climate change and forest diseases. Plant Pathology 60: 133-149 https://doi.org/10.1111/j.1365-3059.2010.02406.x.

Syphard, A.D., J.E. Keeley, and T.J. Brennan. 2011. Comparing the role of fuel breaks across southern California national forests. Forest Ecology and Management 261: 2038-2048 https://doi.org/10.1016/j.foreco.2011.02.030.

Syphard, A.D., J.E. Keeley, A.H. Pfaff, and K. Ferschweiler. 2017. Human presence diminishes the importance of climate in driving fire activity across the United States. Proceedings of the National Academy of Sciences, USA 114: 1375013755 https://doi.org/10.1073/pnas.1713885114.

Talucci, A.C., K.P. Lertzman, and M.A. Krawchuk. 2019. Drivers of lodgepole pine recruitment across a gradient of bark beetle outbreak and wildfire in British Columbia. Forest Ecology and Management 451: 117500 https://doi.org/10. 1016/j.foreco.2019.117500.

Taylor, A.H., V. Trouet, and C.N. Skinner. 2008. Climatic influences on fire regimes in montane forests of the southern Cascades, California, USA. International Journal of Wildland Fire 17 (1): 60-71 https://doi.org/10.1071/WF07033.

Tepley, A.J., F.J. Swanson, and T.A. Spies. 2014. Post-fire tree establishment and early cohort development in conifer forests of the western Cascades of Oregon, USA. Ecosphere 5: 1-23 https://doi.org/10.1890/ES14-00112.1.

Tepley, A.J., J.R. Thompson, H.E. Epstein, and K.J. Anderson-Teixeira. 2017. Vulnerability to forest loss through altered postfire recovery dynamics in a warming climate in the Klamath Mountains. Global Change Biology 23: 41174132 https://doi.org/10.1111/gcb.13704.

Teske, C.C., C.A. Seielstad, and L.P. Queen. 2012. Characterizing fire-on-fire interactions in three large wilderness areas. Fire Ecology 8: 82-106 https://doi. org/10.4996/fireecology.0802082.

Thompson, J.R., T.A. Spies, and L.M. Ganio. 2007. Reburn severity in managed and unmanaged vegetation in a large wildfire. Proceedings of the National Academy of Sciences, USA 104: 10743-10748 https://doi.org/10.1073/pnas.0700229104.

Trenberth, K.E., A. Dai, G. Van Der Schrier, P.D. Jones, J. Barichivich, K.R. Briffa, and J. Sheffield. 2014. Global warming and changes in drought. Nature Climate Change 4: 17-22 https://doi.org/10.1038/nclimate2067.

Trouet, V., A.H. Taylor, A.M. Carleton, and C.N. Skinner. 2006. Fire-climate interactions in forests of the American Pacific coast. Geophysical Research Letters 33: L18704 https://doi.org/10.1029/2006GL027502.

Turner, D.P., D.R. Conklin, and J.P. Bolte. 2015. Projected climate change impacts on forest land cover and land use over the Willamette River Basin, Oregon, USA. Climatic Change 133: 335-348 https://doi.org/10.1007/s10584-015-1465-4.

Turner, M.G., K.H. Braziunas, W.D. Hansen, and B.J. Harvey. 2019. Short-interval severe fire erodes the resilience of subalpine lodgepole pine forests. Proceedings of the National Academy of Sciences, USA 116 (23): 11319-11328 https://doi.org/10.1073/pnas.1902841116.

Vose, R.S., D.R. Easterling, K.E. Kunkel, A.N. LeGrande, and M.F. Wehner. 2017. Temperature changes in the United States. In Climate science special report: fourth national climate assessment, volume I, ed. D.J. Wuebbles, D.W. Fahey, K.A. Hibbard, D.J. Dokken, B.C. Stewart, and T.K. Maycock, 185-206. Washington, D.C.: U.S. Global Change Research Program.

Walsh, M.K., J.R. Marlon, S.J. Goring, K.J. Brown, and D.G. Gavin. 2015. A regional perspective on Holocene fire-climate-human interactions in the Pacific Northwest of North America. Annals of the Association of American Geographers 105: 1135-1157 https://doi.org/10.1080/00045608.2015.1064457.

Walsh, M.K., C.A. Pearl, C. Whitlock, P.J. Bartlein, and M.A. Worona. 2010. An 11,000-year-long record of fire and vegetation history at Beaver Lake, Oregon, central Willamette Valley. Quaternary Science Reviews 29: 1093-1106 https://doi.org/10.1016/j.quascirev.2010.02.011.

Walsh, M.K., C. Whitlock, and P.J. Bartlein. 2008. A 14,300-year-long record of firevegetation-climate linkages at Battle Ground Lake, southwestern Washington. Quaternary Research 70: 251-264 https://doi.org/10.1016/j.ygres.2008.05.002.

Westerling, A.L. 2016. Increasing western US forest wildfire activity: sensitivity to changes in the timing of spring. Philosophical Transactions of the Royal Society B 371: 20150178 https://doi.org/10.1098/rstb.2015.0178.

Westerling, A.L., H.G. Hidalgo, D.R. Cayan, and T.W. Swetnam. 2006. Warming and earlier spring increase western US forest wildfire activity. Science 313: 940943 https://doi.org/10.1126/science.1128834.

Westerling, A.L., and T.W. Swetnam. 2003. Interannual to decadal drought and wildfire in the western United States. EOS, Transactions American Geophysical Union 84: 545-555 https://doi.org/10.1029/2003EO490001. 
Westerling, A.L., M.G. Turner, E.A.H. Smithwick, W.H. Romme, and M.G. Ryan. 2011. Continued warming could transform Greater Yellowstone fire regimes by mid-21st century. Proceedings of the National Academy of Sciences, USA 108: 13165-13170 https://doi.org/10.1073/pnas.1110199108.

Whitlock, C. 1992. Vegetational and climatic history of the Pacific Northwest during the last 20,000 years: implications for understanding present-day biodiversity. Northwest Environmental Journal 8: 5-28.

Whitlock, C., and P.J. Bartlein. 1997. Vegetation and climate change in northwest America during the past $125 \mathrm{kyr}$. Nature 388: 57-61 https:// doi.org/10.1038/40380.

Woolley, T., D.C. Shaw, L.T. Hollingsworth, M.C. Agne, S. Fitzgerald, A. Eglitis, and L. Kurth. 2019. Beyond red crowns: complex changes in surface and crown fuels and their interactions 32 years following mountain pine beetle epidemics in south-central Oregon, USA. Fire Ecology 15: 4 https://doi.org/10. 1186/s42408-018-0010-z.

Worona, M.A., and C. Whitlock. 1995. Late Quaternary vegetation and climate history near Little Lake, central Coast Range, Oregon. GSA Bulletin 107 (7): 867-876 https://doi.org/10.1130/0016-7606(1995)107\%3C0867: LQVACH\%3E2.3.CO;2.

Wright, C.S., and J.K. Agee. 2004. Fire and vegetation history in the eastern Cascade Mountains, Washington. Ecological Applications 14: 443-459 https://doi.org/10.1890/02-5349.

Young, D.J., J.T. Stevens, J.M. Earles, J. Moore, A. Ellis, A.L. Jirka, and A.M. Latimer. 2017. Long-term climate and competition explain forest mortality patterns under extreme drought. Ecology Letters 21: 78-86 https://doi.org/10.1111/ele.12711.

Yue, X., L.J. Mickley, J.A. Logan, and J.O. Kaplan. 2013. Ensemble projections of wildfire activity and carbonaceous aerosol concentrations over the western United States in the mid-21st century. Atmospheric Environment 77: 767-780 https://doi.org/10.1016/.jatmosenv.2013.06.003.

Zedler, P.H., C.R. Gautier, and G.S. McMaster. 1983. Vegetation change in response to extreme events: the effect of a short interval between fires in California chaparral and coastal scrub. Ecology 64: 809-818 https://doi.org/10.2307/ 1937204.

\section{Publisher's Note}

Springer Nature remains neutral with regard to jurisdictional claims in published maps and institutional affiliations.

\section{Submit your manuscript to a SpringerOpen ${ }^{\circ}$ journal and benefit from:}

- Convenient online submission

- Rigorous peer review

- Open access: articles freely available online

High visibility within the field

- Retaining the copyright to your article

Submit your next manuscript at $\boldsymbol{\nabla}$ springeropen.com 